\title{
A Review: Soil Management, Sustainable Strategies and Approaches to Improve the Quality of Modern Viticulture
}

\author{
Eleonora Cataldo*D, Maddalena Fucile and Giovan Battista Mattii \\ Department of Agriculture, Food, Environment and Forestry (DAGRI), University of Florence, \\ 50019 Sesto Fiorentino, Italy; maddalena.fucile@unifi.it (M.F.); giovanbattista.mattii@unifi.it (G.B.M.) \\ * Correspondence: eleonora.cataldo@unifi.it
}

\section{check for} updates

Citation: Cataldo, E.; Fucile, M.; Mattii, G.B. A Review: Soil Management, Sustainable Strategies and Approaches to Improve the Quality of Modern Viticulture. Agronomy 2021, 11, 2359. https://doi. org/10.3390/agronomy11112359

Academic Editors: Othmane Merah, Purushothaman Chirakkuzhyil Abhilash, Magdi T. Abdelhamid, Hailin Zhang and Bachar Zebib

Received: 27 October 2021

Accepted: 20 November 2021

Published: 21 November 2021

Publisher's Note: MDPI stays neutral with regard to jurisdictional claims in published maps and institutional affiliations.

Copyright: (c) 2021 by the authors. Licensee MDPI, Basel, Switzerland. This article is an open access article distributed under the terms and conditions of the Creative Commons Attribution (CC BY) license (https:// creativecommons.org/licenses/by/ $4.0 /)$.

\begin{abstract}
Conservative and sustainable soil management in vineyards is an approach of primary importance not only for the yield (tons per hectare) and grapes' quality (primary and secondary metabolites), but also for the greater preservation of the ecosystem. Compared to sustained-conventional tillage and perpetual applications of fertilizers and phytopharmaceutical, these techniques give a primary role for safeguarding biodiversity, conserving soil fertility, and keeping vegetative-productive balance. The soil and, consequently, the wine production are in fact an intimate ecosystem jeopardized not only by a reckless approach by man (technical input, such as pesticides, fuel, fertilizers, and herbicides, are estimated to be responsible for $24 \%$ of anthropogenic greenhouse gases emissions), but also by climate change, as rising summer temperatures and reduced precipitation leads to production declines and water shortages in the soil. In fact, there are several risks associated with unbalanced soil management, such as compaction, pollution, soil erosion, soil organic matter (SOM) depletion, and loss of biodiversity, that lead to a drop in grape quality and quantity. In this context, soil management in viticulture and sustainable strategies assume greater significance to improve the quality of modern viticulture. This review aims to highlight new agronomic techniques capable of enhancing the resilience of the system and contributing to conservation and ecosystem services provision, especially as wine consumers increasingly appreciate environmentally friendly farming practices. In particular, the review aims to focus the positive implications and repercussions as a result of these practices (e.g., compost, vermicompost, biochar, Ascophyllum nodosum, Arbuscular mycorrhizal fungi (AMF), Trichoderma, zeolite, partial root drying, cover cropping, and mulching).
\end{abstract}

Keywords: soil organic matter; zeolite; biostimulants; global warming; compost; cover crop; mulching; tillage

\section{Introduction}

Vine cultivation is an important economic sector in global agriculture and a cultural legacy in many regions around the world [1]. However, in several vineyards, ecosystem services are particularly endangered because the function of the soil is often compromised by agricultural practices, repeated over time, for the management of pests and weeds that prove to be incorrect and harmful [2]. There are several risks associated with unbalanced soil management, such as compaction [3], pollution [4], soil erosion [5], soil organic matter (SOM) depletion [6], and loss of biodiversity, that lead to a drop in vine quality and quantity [7]. For instance, the long abuse of synthetic fertilizers represents a serious, threatening remark to the vineyard environment, as it negatively reshapes the humic-mineral and microbiological context of the soil with consequent progressive loss of fertility until biological desertification is reached [8].

Synthetic fertilizers and fungicides contain heavy metals, notably copper $(\mathrm{Cu})$, mercury $(\mathrm{Hg})$, cadmium $(\mathrm{Cd})$, zinc $(\mathrm{Zn})$, arsenic $(\mathrm{As})$, lead $(\mathrm{Pb})$, and nickel $(\mathrm{Ni})[9,10]$; in particular, the continued abuse of $\mathrm{Cu}$-based fungicides $\left(\left(\mathrm{CuSO}_{4}+\mathrm{Ca}(\mathrm{OH})_{2}\right) ; \mathrm{CuSO}_{4} \cdot 3 \mathrm{Cu}(\mathrm{OH})_{2}\right.$; $\mathrm{Cu}_{2} \mathrm{O} ; \mathrm{Cu}(\mathrm{OH})_{2} ; \mathrm{CuCl}_{2} \cdot 3 \mathrm{Cu}(\mathrm{OH})_{2}$, etc. [11]) leads a risk of soil contamination because 
the copper residues accumulate in the vineyards and remain in the soil ecosystems after application for a long time. This phenomenon leads to problems in the quality of the finished product (atrophy of the root system of the new plants, toxicity on leaves and stems, $\mathrm{Cu}$-contamination in wine and the formation of copper casse) [12-15].

In addition to the nightmare scenario of soil resource impoverishment and contamination, the context regarding climate change is adjoined [16]. This general concern about the impact of climate change on viticulture is generated by the well-recognized strong influence that climate has on soil moisture and the quantity and quality of wine produced [17]. For example, higher temperature's effects on the long-term sustainability of wine grape production are a well-recognized point at issue [18,19]. In particular, in Europe, the summer heatwaves and the observed warming trend over recent decades have originated apprehensiveness among winemakers and raised doubts about the profitability prospect of the wine grape industry $[20,21]$. High transpiration rates at higher temperatures lead to a rapid decline in soil moisture; during drought, soil moisture-driven changes in photosynthesis have a negative impact on the whole-plant carbon balance, which has a repercussion on the quality of the grapes [22-24].

It is in this context that soil management in viticulture and sustainable strategies assumes greater significance to improve the quality of modern viticulture. Several authors compared vineyard soil characteristics and grape quality under different grass management practices (e.g., different types of row grassing: Trifolium incarnatum, Hordeum vulgare, Festuca arundinacea, Brassica juncea, Lolium perenne, Festuca ovina, and Poa pratensis) $[25,26]$ and after organic or inorganic fertilizer application $[27,28]$. In fact, soil chemistry and sustainable soil management in vineyards are directly correlated with wine grape quality [29]. On the one hand, the enhancement of the intrinsic properties of soil (innate physicochemical characteristics) and the sustainable management of the other (conservative approach of this resource) positively influence the quality of the product. Vineyard soil management includes diverse agricultural practices that all influence soil functioning. Soil organic fertilization improves the soil structure and SOM content (with contrasting results depending on both quantity and quality of the organic matter applied) [30]. Conversely, mechanical weeding can dwindle the SOC (soil organic carbon) content, modify soil biological communities at different trophic levels, and induce physical degradation of vineyard soils, lowering the quality of the grapes [31]. Moreover, cover crop in inter-rows contributes to needed services, such as water infiltration, nutrient supply and retention, carbon sequestration, and reduction in soil erosion [32-34].

The present paper reviews different approaches to soil management and their important implications in viticulture. The manuscript also calls for greater involvement of scientists in essential investigations into the sustainability of such practices for future development in accordance with the new green economy directives.

\section{Factors Affecting Soil Quality}

Soil is a non-renewable resource [35] because its regeneration is through chemical and biological processes of rock weathering, which requires geological time scales [36]. Firstly, in general, soil has fundamental environmental functions inclusive of fauna habitat, the provision of ecosystem services, and biodiversity support [37]. In addition, in agricultural ecosystems, soil takes on other multiple connotations, such as biodiversity, nutrition, source of productivity, and water storage [38-40]. Therefore, an important component of soil assessment is its quality, with the identification of a set of specific attributes that reflect its capacity to function and that can be used as indicators of soil quality. Soil quality can be evaluated both for natural ecosystems, where major purposes are the maintenance of environmental quality and biodiversity conservation, and for agro-ecosystems, where the main, but not exclusive, ecosystem service is productivity [41]. However, the soil quality concept can be described as "the soil ability to operate within ecosystem frontiers to maintain environmental quality, sustain biological productivity, and forward plant and animal salubrity and fitness" [42,43]. In fact, soil quality is immediately correlated with 
its functions, for instance, supplying a base for plant growth, regulating water supply, modulating biological populations, and reserving nutrients [44].

Chemical, physical, or biological indicators generally evaluate soil quality [45]. Among chemical and physical indicators, in viticulture, those most used are, for example, $\mathrm{pH}$, soil bulk density, availability of principal nutrients $(\mathrm{N}, \mathrm{P}, \mathrm{K}, \mathrm{Ca}, \mathrm{Mg})$, and organic matter content that increases soil water holding capacity, promotes soil aggregation and constitutes a pool of available nutrients [46-48]. Soil organic matter (SOM) is affirmed as an influential regulator of several environmental constraints to crop productivity by decreasing the exchangeable sodium (Na) percentage and electrical conductivity (EC), accelerating salt leaching, as well as increasing water infiltration, the water-holding capacity, and aggregate stability [49,50]. Bioindicators or biological indicators provide an evaluation of soil functioning; soil organisms have particular relationships with their surroundings, as they can give information about soil improvement or degradation [51]. Microorganisms, nematodes, and earthworms are involved in several key processes in the ecosystems, such as nutrient retention and cycling, humus formation, organic matter decomposition, soil aggregation, and different symbiotic and parasitic relationships with plants [52-54].

Land soil degradation is one of the most important causes of quality soil losses that results in the loss of services, resources, and goods. Soils in vineyards are also important to balance the erosional, hydrological, geochemical, and biological earth cycles [55,56]. In semi-arid regions, several aspects of soil degradation are obvious, such as soil salinization and erosion $[57,58]$. However, salinization is a worldwide issue that should be remediated [59]. Salinity is one of the dangerous parameters of soil quality because it is causing increasing agricultural problems all around the world; it is a major contributing factor that reduces plant growth and consequently agricultural productivity $[60,61]$.

In semi-arid countries, the climate natural characteristics, such as warm dry summers, prolonged drought, and heavy rainfall during the autumn, with inadequate soil management lead to a reduction in land organic matter content [62]. This scenario has a negative influence on soil biological, physical, and chemical properties and their processes, causing structural and texture degradation with loss of fertility [63]. For instance, in southeast Spain, there are several areas where these events are becoming a serious problem because there is an uninterrupted drop of SOM and enhanced use of saline irrigation water that leads to prompt desertification [64]. New techniques and sustainable strategies are required to mitigate this deterioration in soil quality.

\section{Soil Management in Viticulture}

Intensive agriculture was demonstrated to seriously affect water, soil quality, and vines quantity or quality [65]. Mediterranean vineyards are vulnerable to serious risk of soil quality deterioration, owing to loss of organic matter, erosion, fertilizer contamination, and compaction. In addition, in intensive viticulture, the perpetual working activities that use heavy machinery and incessant tillage are responsible for increasing soil erosion rates and $\mathrm{CO}_{2}$ emissions [66]. This scenario, also considering the likely climate change impacts, showed doubts about its long-term sustainability [67]. It was reported that vineyard soil erosion, owing to a single extreme rainfall event, can induce a nutrient loss of $12 \%$ (N annual applied) and 60\% (P annual applied) [68]. As a result, analysis and research focus more on innovative management strategies to improve soil fertility, reduce the nutrient loss on the surface, in groundwater, balance water consumption, and increase grape quality [69]. All this makes the cultivation and management of white grapes very delicate. It is, therefore, necessary that the winemaker, following climate change, implements a series of strategies aimed at preserving and enhancing the aromatic potential of white grape varieties to optimize harvesting.

\subsection{Compost}

The composting process is an aerobic microbiological mechanism, which is promoted by fungi and bacteria during which organic waste is biologically degraded by these mi- 
croorganisms to humus-like material. Composting is a valid method to produce fertilizer or soil improver [70]. However, the final product must not contain viable seeds or pathogens (reference thresholds provided by national legislation), and it should be stable and suitable for use as a soil amendment [71]. The composting results are carbon dioxide $\left(\mathrm{CO}_{2}\right)$ and stable forms of carbon $(\mathrm{C})$; the process consists of the decomposition and mineralization of organic matter and the production of humic substances [72]. Many connected parameters, such as temperature $\left(55-65^{\circ} \mathrm{C}\right.$ thermophilic phase and $35-45^{\circ} \mathrm{C}$ mesophilic phase [73]), oxygen content, aeration rate (i.e., $0.43-3.44 \mathrm{~L} \mathrm{~min}^{-1} \mathrm{~kg}^{-1}$ [74]), moisture, feed composition, moisture, $\mathrm{C} / \mathrm{N}$ ratio (i.e., 13.9-19.6 [75]), and $\mathrm{pH}$ (6-8 [76]) affect the composting process and the final product [77]. Composting may result from waste from landfills [78], green waste and food waste [79], municipal solid waste [80], leftovers of raw fruit and vegetables [81], and pruning wastes [82].

Annually, the wine industry uses big amounts of chemical fertilizers and organic matter. Organic matter input constitutes an important way for soil fertility restoration and regeneration, and it has become a conventional practice in such salt-affected soils $[83,84]$. In this scenario, the possibility of recovering organic wastes from the wine industry to vineyards may be presented as a sustainable strategy for waste management; chemical fertilizer's exclusive addition is no longer considered the best method to feed the vine and control plant pathogens [85]. The main organic wastes include dewatered sludge (12\%), stalk $(12 \%)$, lees $(13 \%)$, and grape pomace (63\%) [86]. It was shown that the soil treatment with compost from winery wastes increased the SOM percentages, microbial biomass, nutrient levels (providing a slow fertilization action), and improved vines performance, enhancing the soil's physical properties (water-holding capacity, aeration, etc.) [87]. An experimental vineyard located in Timişoara city (Otonel variety) composted with $20 \mathrm{t} / \mathrm{ha}$ grape pomace showed greener foliage, had fewer nutrient deficiencies in the leaves, suffered less from drought, and had a better reaction to the disease [88]. The results about the long-term application of green waste compost, on Chardonnay cv., demonstrated that long-term addition of compost to a vineyard could be beneficial to soil characteristics, including nitrate content and organic matter, but has no effects on plant growth and grape quality [89].

The effect of organic amendments on soil quality indicators and agronomic variables in table grape Thompson seedless cv. was evaluated; different treatments, including compost from grape pomace, humic extract, microbial inoculant, and chemical NPK fertilization, were applied in a pot experiment using Inceptisol soil. The results showed a stronger root development in plants with compost and microbial inoculant application. Furthermore, organic matter mineralization increased nutrient availability; this was evidenced by an increment of enzymatic activities, particularly $\beta$-glucosidase, acid phosphatase, and alkaline phosphatase, in all treatments receiving compost [90].

From 2009 to 2013, the effect of two compost applications (compost from vine pruning waste and from cattle manure) on soil fertility, vine below-aboveground growth, yield, and grape quality was investigated in Cabernet Sauvignon vines in Northeastern Italy [91]. A positive effect of compost on root growth was recorded only for compost from pruning waste, increasing total root density for fine $(<1 \mathrm{~mm})$ and medium $(1-2 \mathrm{~mm})$ roots, while compost from cattle manure did not show a significant influence on the root system. Compost from cattle manure provided the same total $\mathrm{N}$ amount as from pruning waste (15-20 N units/ha/y). Contrary to what was reported by Pinamonti [92] and Morlat [47], a significant increase in yield was observed by 15-20\% (higher number of bunches and higher bunch weight). Finally, compost treatments balanced the overall quality of the grapes; there was a significant reduction in total soluble solids (resulting in a drop in the alcohol content) combined with excellent levels of total anthocyanins and flavonoids.

In light of the results obtained, it is believed that composting is a suitable way of organic waste valorization, according to Circular Economy principles (sustainability). In addition, the feasibility of using compost as an organic fertilizer in vineyards is demonstrated, avoiding the use of synthetic fertilizers. 


\subsection{Vermicompost}

Vermicompost is represented by earthworm excreta that are able to enhance nutrients and the status of soil health. Vermiculture is a process by which biodegradable wastes, such as kitchen wastes, bio-wastes of agro-based industries, farm wastes, market wastes, and livestock wastes, passing through the worm gut, are transformed to nutrient-rich vermicompost. Worms are biological agents capable of consuming wastes and depositing excreta in this process [93]. This process involves a symbiotic interaction between some earthworms, such as Eisenia fetida, Eudrilus eugeniae, and Perionyx excavatus, and microorganisms [94]. Vermicomposting differs from composting in some respects (Figure 1) $[95,96]$.

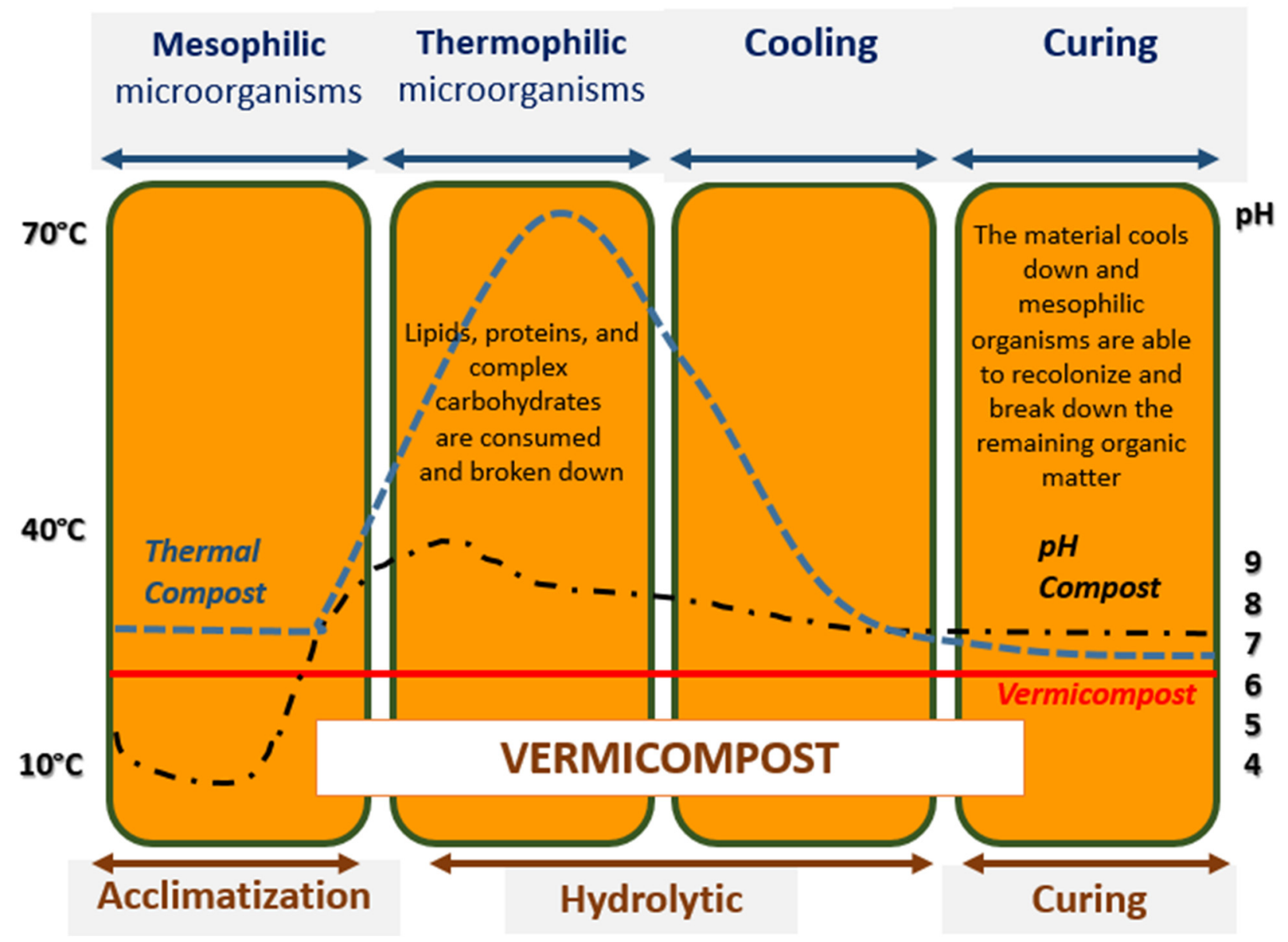

Figure 1. Theoretical pH vs. temperature curves for thermogenic (thermal) compost and vermicompost. Blocks represent major phases in the process.

In general, owing to the mineralization rate of organic matter being faster, giving a higher degree of humification, vermicompost is biochemically, physically, and nutritionally improved over traditional compost. In addition, vermicomposting generates two useful products: the earthworm biomass and vermicompost [97].

The $\mathrm{C} / \mathrm{N}$ ratio and $\mathrm{NO}_{3} / \mathrm{NH}^{4+}$ ratio are important indicators of vermicompost maturity. A C/N ratio lower than 20 manifests a satisfactory organic matter stabilization degree. On the one hand, during the vermicomposting process, carbon is released as carbon dioxide $\left(\mathrm{CO}_{2}\right)$; on the other, the production of mucus and nitrogen excrements increase the nitrogen levels, reducing the vermicompost $\mathrm{C} / \mathrm{N}$ ratio [98]. During the vermicomposting process, by the nitrification process, elevated levels of $\mathrm{NH}^{4+}$ are released and converted into $\mathrm{NO}_{3}$. A decrease in $\mathrm{NH}^{4+}$ and an increase in $\mathrm{NO}_{3}$ provide an overall growth of the $\mathrm{NO}_{3} / \mathrm{NH}^{4+}$ ratio, indicating stable vermicompost [99]. 
Vermicompost enhances soil fertility not only biologically but also physically, and chemically. Physically, the treated soil has better bulk density, aeration, porosity, and water retention. Chemically, electrical conductivity, $\mathrm{pH}$, and organic matter content are enhanced leading to better crop yield [100]. In fact, the abuse of inorganic fertilizers without organic supplements deteriorates land chemical and physical properties and pollutes the surrounding environment [101]. It was observed that the addition of vermicompost (20 t/ha) to agricultural soil, over two consecutive years, significantly improved aggregate stability and soil porosity [102], improving the availability of air and water and encouraging root growth [103].

In the region of Valdeorras (Northwest Spain), a grape marc from the wine was used for the production of vermicompost $(\mathrm{C} / \mathrm{N}$ ratio of 16 and dissolved organic carbon DOC of $4.2 \mathrm{~g} \mathrm{~kg}^{-1}$ ) using fertilizer in a vineyard soil of the same area [104]. It is to be borne in mind that the use of grape marc as an amendment, in general, presents a series of disadvantages for direct soil application: seasonal production, acidity, high $\mathrm{C} / \mathrm{N}$ ratio, and phytotoxic compounds presence, such as organic acids, phenolics, and ethanol [105]. The rates of grape marc vermicompost that should be added to the vineyard in order to maintain the levels of organic matter were estimated to be $1.7 \mathrm{t} / \mathrm{ha}$ /year of bulk vermicompost (with the present mean temperature) and $2.1 \mathrm{t} / \mathrm{ha}$ /year of bulk vermicompost (with a $2{ }^{\circ} \mathrm{C}$ increment in temperature). This is a sustainable solution to reduce the amount of such abundant agro-industrial waste to be disposed of. In fact, a vineyard could produce up to 15 tons per hectare of grape, where grape marc represents up to $20 \%$ of the total weight of the grape collected. Assuming that grape marc might suffer a maximum 35\% and $42 \%$ weight reduction during vermicomposting and composting, respectively, the amount of grape marc compost that may be prepared would be around $1.2 \mathrm{t} /$ ha [106].

Applications of vermicompost in a vineyard of Mendoza in Argentina [107] and in Piedmont and Tuscany in Italy [108] increased the yield and nutrient content in the soil and in the vines. Positive effects of high dose vermicompost fertilizer (worms were fed with fermented feed obtained from a mixture of $20 \%$ herbal waste and $80 \%$ cow dung) were observed in applications irrigated with biogas liquid fertilizer (BS). Positive increases were observed in $\mathrm{N}, \mathrm{P}, \mathrm{Ca}, \mathrm{Mg}, \mathrm{Fe}$, and $\mathrm{Cu}$ elements, especially in BS applications with increasing doses of vermicompost [109].

A recent study [110] showed that in soils with high $\mathrm{Cu}$ contents, vermicompost effectively reduced $\mathrm{Cu}$ phytotoxicity in young vines grown. Here, three different amendments were applied to the soil: vermicompost (30 $\mathrm{g}$ of $\left.\mathrm{C} \mathrm{kg}^{-1}\right)$, limestone $\left(3 \mathrm{Mg} \mathrm{ha}^{-1}\right)$, and calcium silicate ( $3 \mathrm{Mg} \mathrm{ha}^{-1}$ ). The vermicompost and calcium silicate led to a significant alkalization of the soil solution. In addition, for vermicompost treatment, the levels of $\mathrm{Cu} 2+$ in the soil solution were diminished with a clear benefit for plants $(+89 \%$ biomass accumulation at the shoot level). Moreover, it led to a higher photosynthetic rate, a higher percentage of fine roots with a $0.2 \mathrm{~mm}$ diameter (particularly active in water and nutrient acquisition), lower guaiacol peroxidase (POD, EC 1.11.1.7), and superoxide dismutase (SOD, EC 1.15.1.1) activity.

Vermicompost does appear to be a relevant alternative to chemical fertilizers because it leads to similar enhancements in plant growth while increasing soil quality and decreasing nutrient leaching.

\subsection{Biochar}

Biochar is a solid material that is produced after the pyrolysis (thermal processing) of industry by-products, municipal wastes, and agricultural waste (such as grape pomace) at temperatures between $300{ }^{\circ} \mathrm{C}$ and $800{ }^{\circ} \mathrm{C}$ under no or low oxygen conditions. The feedstock type and pyrolysis conditions influence biochar physicochemical properties. Biochar enhances soil quality, increasing its moisture-holding capacity, $\mathrm{pH}$, cation exchange capacity, crop yield, and encouraging the beneficial activity of fungi and microbes [111]. In addition, it sequesters carbon from the atmosphere biosphere pool and transfers it to the soil. Biochar is rich in highly stable carbon (i.e., 98\%), characterized 
by micro and macroporosity that decomposes more slowly than normal compost [112]. Thus, the application of biochar to vineyards theoretically can improve vine growth and especially fruit quality [113]. However, significant improvements in soil fertility, yield, and plant growth were mostly shown in tropical and subtropical soils $[114,115]$. In fact, Schmidt et al. [113] showed that over three years, biochar ( $8 \mathrm{t} / \mathrm{ha}$, produced from wood at $\left.500{ }^{\circ} \mathrm{C}\right)$ and biochar-compost $(8 \mathrm{t} / \mathrm{ha}+55 \mathrm{t} / \mathrm{ha}$, mixed before the composting process) treatments led only to economically irrelevant and non-significant effects. In this study, the topsoil application of biochar had no immediate economic value for vine growing in poor fertility, temperate soil, and alkaline. On the contrary, Baronti et al. [116] showed that, over two consecutive growing seasons, the application of two biochar rates (22 and $44 \mathrm{t} / \mathrm{ha}$ ) obtained from the carbonization of orchard pruning waste increased the available soil water content, compared to control soils (from 3.2\% to $45 \%$ in the 22 and $44 \mathrm{t} / \mathrm{ha}$ application rates, respectively), and the leaf water potential (24-37\%) during droughts. Even if few studies were conducted on the hydrophobicity of the soil-biochar mixture, the biochar molecular structure is highly hydrophobic and could theoretically improve the water repellency of soil surface with potential impacts upon soil erosion [117]. Other biochar applications (22 $\mathrm{t} / \mathrm{ha}$ /year) substantially increased vineyard production in all harvest years, emphasizing also the role of biochar in increasing plant water availability in dry years. The biochar used was a commercial low temperature $\left(500^{\circ}\right)$ slow pyrolysis biochar derived from orchard pruning feedstock (Ravenna, Italy) [118]. The amelioration of sandy soils using biochar amendment, improving water-holding (particularly at field capacity), was shown in a recent study. The product was made by pyrolysis at $400-700{ }^{\circ} \mathrm{C}$ of grapevine cane and stalks [119].

However, pot trials are recommended to confirm the water-retention behavior and commercial feasibility.

Biochar also provided ecosystem services by reinforcing the microbial community. It increased microbial biomass, enzyme activities (phosphatase, arylsulfatase), phospholipid fatty acids (PLFAs), and bacterial taxa abundances (Firmicutes, Gemmatimonadetes, Actinobacteria, $\alpha$-Proteobacteria, and $\beta$-Proteobacteria) [120]. The biochar ( $<5 \mathrm{~mm}$ dimension) was produced from $80 \%$ varied hardwood and $20 \%$ varied coniferous wood chips. Pyrolysis took place in a "Schottdorf"-type reactor (Carbon Terra GmbH, Augsburg, Germany) at $750{ }^{\circ} \mathrm{C}$ in a $36 \mathrm{~h}$ cycle.

Other results [121], in Montepulciano vineyards, Italy, showed that biochar's effects on soil fertility and functions were maintained in the long term (7 years) after a one-time application. The biochar was produced by slow pyrolysis $\left(500^{\circ} \mathrm{C}\right)$ of orchard prunings, and its application was at a rate of $22 \mathrm{t} / \mathrm{ha}$ /year on the inter-row space of the vineyard by a spreader, mechanically mixed into the soil to a depth of $0.3 \mathrm{~m}$ using a chisel plow tiller. The $\mathrm{pH}$, total organic $\mathrm{C}$ (TOC), total $\mathrm{P}$ concentrations, soil microbial biomass, and soil respiration were substantially increased in biochar-amended soils. In addition, the significant reduction in protease and urease activities in the biochar-amended soils reflected the increased $\mathrm{N}$ availability, particularly nitric-N. In treated soil, the higher emission of $\mathrm{C} 4$ aldehydes showed an intense activity of oxidative pathways of terminal C of the C4 compounds, leading to butyraldehyde/butyric acid, mainly active for energy production in microorganisms.

\subsection{Ascophyllum Nodosum}

Natural plant biostimulants (PBs) were defined as: "A plant biostimulant is any substance or microorganism applied to plants with the aim to enhance nutrition efficiency, abiotic stress tolerance and/or crop quality traits, regardless of its nutrient content" [122]. Recently under the new Regulation (EU) 2019/1009, the definition was stated as the following: "A plant biostimulant shall be an EU fertilising product the function of which is to stimulate plant nutrition processes independently of the product's nutrient content with the sole aim of improving one or more of the following characteristics of the plant or the plant rhizosphere: (i) nutrient use efficiency, (ii) tolerance to abiotic stress, (iii) quality 
traits, or (iv) availability of confined nutrients in the soil or rhizosphere" [123]. There were proposed six non-microbial and three microbial categories of PBs [124] (Table 1).

Table 1. Non-microbial (N-M) and microbial (M) categories of PBs: chitosan, humic and fulvic acids (HA and FA), protein hydrolysates (PHs), phosphites, seaweed extracts, silicon (Si), arbuscular mycorrhizal fungi (AMF), plant growth-promoting rhizobacteria (PGPR), and Trichoderma spp.

\begin{tabular}{|c|c|c|c|}
\hline Categories of PBs & Class & Description & Bibliography \\
\hline Chitosan & N-M & $\begin{array}{c}\text { Chitosan is formed from chitin, a co-polymer of } \\
\mathrm{N} \text {-acetyl-d-glucosamine and d-glucosamine, when over } 80 \% \text { of } \\
\text { the acetyl groups of the } \mathrm{N} \text {-acetyl-d-glucosamine residues } \\
\text { are removed. }\end{array}$ & [125] \\
\hline $\begin{array}{l}\text { Humic and fulvic acids } \\
\text { (HA and FA) }\end{array}$ & N-M & $\begin{array}{l}\text { FA are associations of small hydrophilic molecules in which there } \\
\text { are enough acid functional groups to keep the fulvic clusters } \\
\text { dispersed in solution at any } \mathrm{pH} \text {, while HA are made of } \\
\text { associations of predominantly hydrophobic compounds } \\
\text { (polymethylenic chains, fatty acids, steroids compounds) which } \\
\text { are stabilized at neutral pH by hydrophobic dispersive forces } \\
\text { (van der Walls, } \pi-\pi \text {, and CH- } \pi \text { bonds). }\end{array}$ & [126] \\
\hline $\begin{array}{l}\text { Protein hydrolysates } \\
\text { (PHs) }\end{array}$ & $\mathrm{N}-\mathrm{M}$ & $\begin{array}{l}\text { PHs are mixtures of polypeptides, oligopeptides and amino acids } \\
\text { that are manufactured from protein sources using } \\
\text { partial hydrolysis. }\end{array}$ & [127] \\
\hline Phosphites & N-M & $\begin{array}{l}\text { Phosphite }\left(\mathrm{H}_{2} \mathrm{PO}_{3}{ }^{-}\right) \text {, a reduced form of phosphate (Pi), is an } \\
\text { isostere of the phosphate anion }\left(\mathrm{H}_{2} \mathrm{PO}_{4}^{-}\right) \text {, in which one of the } \\
\text { oxygen atoms bonded to the } \mathrm{P} \text { atom is replaced by hydrogen. }\end{array}$ & [128] \\
\hline Seaweed extracts & N-M & $\begin{array}{l}\text { Seaweeds are a diverse assemblage with close to 10,000 species of } \\
\text { red, brown and green seaweeds described. Ascophyllum nodosum, } \\
\text { Ecklonia maxima, Macrocystis pyrifera and Durvillea potatorum are } \\
\text { the most frequently commercially used by the extract industries. }\end{array}$ & [129] \\
\hline Silicon (Si) & N-M & $\begin{array}{l}\mathrm{Si} \text { is the second most abundant element in the earth's crust, it is } \\
\text { not considered an essential element for plant nutrition. In the soil } \\
\text { solution, } \mathrm{Si} \text { occurs mainly as monomeric silicic acid }\left(\mathrm{H}_{4} \mathrm{SiO}_{4}\right) \text { at } \\
\text { concentrations ranging from } 0.01 \mathrm{mM} \text { to } 2.0 \mathrm{mM} \text {. } \mathrm{H}_{4} \mathrm{SiO}_{4} \text { does } \\
\text { not dissociate at pH lower than } 9 \text { and thus, plants take up } \mathrm{Si} \text { in } \\
\text { this non-ionic form, actively or passively. }\end{array}$ & [130] \\
\hline $\begin{array}{l}\text { Arbuscular mycorrhizal } \\
\text { fungi (AMF) }\end{array}$ & M & $\begin{array}{l}\text { AMF can only be grown in the presence of obligate symbionts } \\
\text { (host plants), and are widely used in horticulture, in particular } \\
\text { Rhizophagus intraradices and Funneliformis mosseae. AMF } \\
\text { symbiosis is particularly important for enhancing the uptake of } \\
\text { the relatively immobile and insoluble phosphate ions in soil, due } \\
\text { to interactions with soil bi- and trivalent cations, principally } \mathrm{Ca}^{2+} \\
\qquad \mathrm{Fe}^{3+} \text {, and } \mathrm{Al}^{3+} \text {. }\end{array}$ & [131] \\
\hline $\begin{array}{l}\text { Plant growth-promoting } \\
\text { rhizobacteria (PGPR) }\end{array}$ & M & $\begin{array}{l}\text { PGPR includes } 3 \text { types of soil bacteria, depending on their } \\
\text { lifestyle: free-living bacteria inhabiting the zone around the root } \\
\text { (rhizosphere), those that colonize the root surface (rhizoplane), } \\
\text { and endophytic bacteria that live within roots. Bacilli spp., } \\
\text { Alphaproteobacteria spp., Betaproteobacteria spp., } \\
\text { Gammaproteobacteria spp., Actinobacteria spp. }\end{array}$ & [132] \\
\hline Trichoderma spp. & M & $\begin{array}{c}\text { Trichoderma (teleomorph Hypocrea, Ascomycota, Dikarya) is a } \\
\text { well-studied fungal genus that consists of more than } \\
200 \text { molecularly defined species. It belongs to a class of PGPF that } \\
\text { was successfully used for biological control of phytopathogens, } \\
\text { such as Fusarium oxysporum, Rhizoctonia solani, Armillaria mellea, } \\
\text { and Chondrostereum purpureum. }\end{array}$ & [133] \\
\hline
\end{tabular}

Seaweed extracts (SWE) represent an important category of organic non-microbial PBs. SWE are highly considered to be efficient and sustainable tools not only for securing yield stability under low input (i.e., biofertilizer effects), but also as an innovative strategy to enhance crop tolerance to abiotic stressors, such as drought, extreme temperatures, and salinity [134]. Seaweeds are an important source of enzymes, polysaccharides, polyunsaturated fatty acids (PUFAs), and bioactive peptides [135]. De Saeger et al. [136] stated that "Ascophyllum nodosum extracts affect the endogenous balance of plant hormones by 
modulating the hormonal homeostasis, regulate the transcription of a few relevant transporters to alter nutrient uptake and assimilation, stimulate and protect photosynthesis, and dampen stress-induced responses".

The most widely seaweed used, as a source for PBs, is the brown, inter-tidal seaweed Ascophyllum nodosum, a rich source of various bioactive phenolic compounds, such as phlorotannins and unique polysaccharides (i.e., laminarin (4.5\%), mannitol (7.5\%), fucoidans (11.6\%), and alginic acid (28\%)) [137].

On the contrary by Frioni et al., [138] the seaweed extract of Ascophyllum nodosum, used as soil conditioners by Popescu et al. [139], influenced vegetative growth expressed by the length and diameter of the shoot and leaf area of vine stock. In Australia, the seaweed extract treatment was soil-applied at a $10 \mathrm{~L} /$ ha dose during various phenological stages (at woolly bud and $10 \mathrm{~cm}$ shoot growth, budburst, flowering, fruit set, and veraison), improving wine grape yield by $14.7 \%$ across multiple growing years [140].

Seaweed-based extracts were recently employed as sustainable tools to improve abiotic stress tolerance, increase nutrient uptake and grape quality. However, the effects of its application into the soil are not yet fully understood [141]; the effect of these soil applications on secondary metabolism compounds, which are fundamental for the quality of grapes and wine, is still scarcely known. More information is known about the use of this biostimulant by foliar application. Therefore, given the patchwork of benefits that these foliar products have on the plant, and given their usability also in organic management, it would be appropriate to investigate the effects of biostimulants applied to the soil.

\subsection{Arbuscular Mycorrhizal Fungi}

Arbuscular mycorrhizal fungi (AMF) constitute an integral and important component of the vineyard ecosystem with significant applications for sustainable agricultural ecosystems [142].

In vineyard production systems, AMF (Glomus intraradices, Glomus macrocarpum, Glomus mosseae and Paraglomus occultum) have an increasingly important role, owing to water stress and low fertile soils [143]. Comparing with non-inoculated grapevines, grapevines that were AMF-treated led to expanded shoot growth [144], and enhanced drought tolerance [145] and nutrient uptake [146].

\subsection{Trichoderma spp.}

Saprophytic fungi that are negatively affected by elevated salt concentrations are fundamental and frequent elements of rhizosphere soil [147]. High salt concentrations, due to the lower microbial biomass, reduce the solubility of enzyme proteins and denature them through disruption of the tertiary protein structure essential for enzymatic activities; $\beta$-glucosidase and phosphatase activities were found to be negatively affected by salt $[148,149]$. Enzymatic activities and higher microbial biomass are positive parameters that show soil health and suggest that microorganisms transform soil nutrients and mineralize those organic compounds to recycle organic substrates [150].

Trichoderma spp., which has the ability to survive under unfavorable conditions (salt and drought), was positively used as beneficial microorganisms for their capacity to inhibit several fungal plant pathogens. They are important competitors in the rhizosphere, are resistant to soil fungicides, and are efficient in utilizing soil nutrients and also promoting plant growth [151-154]. Trichoderma spp., which can mineralize organic nutrients by producing large quantities of extracellular enzymes, reduces chemical inputs, such as biofertilizers, promoting sustainable agriculture and natural resources conservation $[155,156]$. These rhizosphere microorganisms liberate extracellular enzymes for starting the degradation of high molecular polymers that lead to the death of negative plant pathogenic fungi [157].

Mbarki et al. [158] tested the feasibility of inoculating Trichoderma harzianum T78 at high salt concentration levels with compost, comparing with non-amended soils. Soil biological parameters (biomass $\mathrm{C}$, fungi and bacteria colony-forming units, and dehydrogenase 
activity), biochemical parameters (dehydrogenase, glucosidase, phosphatase, and urease activities), and T. harzianum survival were monitored. Amended soils showed significantly higher $\beta$-glucosidase and phosphatase activities with an increase in hydrolytic enzymes related to a better microbial pool, thanks to the higher physiological capacity.

A recent work successfully verified the efficacy of Trichoderma-based products on the fertility maintenance in vineyard soils in the case of replanting during the engrafting of rooted cuttings [159].

Biofumigation with white mustard plants combined with Trichoderma spp. root treatment improved the control of black-foot disease in grapevines. This control strategy can reduce soil inoculum levels and protect plants from infection, improving their performance [160].

Trichoderma spp. were considered highly effective biological control agents BCAs of Xylotrechus arvicola in vineyards. The soil Trichoderma spp. (harzianum and gamsii) application was used to inhibit egg development of X. arvicola (Olivier) (Coleoptera: Cerambycidae) and to prevent larvae from boring into vines and killing adults [161]. In addition, nursery and vineyard experiments were set up to evaluate the ability of Trichoderma atroviride SC1 to reduce infections of fungal grapevine trunk disease (GTD) pathogens in grapevine planting material during the propagation process. Cuttings of $110 \mathrm{R}$ rootstock subsequently grafted with Tintorera $\mathrm{cv}$. were treated with T. atroviride $\mathrm{SC} 1$ at three stages during the grapevine propagating process:

1. One-day soak in T. atroviride SC1 suspension prior to grafting.

2. Application of T. atroviride SC1 suspension in sawdust at stratification.

3. One-hour soak of the basal parts of the plants in T. atroviride SC1 suspension before planting in the rooting field.

The results indicated that T. atroviride SC1 reduced infections caused by GTD pathogens [162].

\subsection{Zeolite}

Zeolites are extensively used for agricultural and human uses; in fact, the International Agency for Research on Cancer (IARC) classified zeolites as non-toxic products, and the Food and Drug Administration (FDA) categorized them as safe for human consumption, so zeolites are extensively used in agriculture [163]. Zeolites are crystalline aluminosilicates of alkali and alkaline earth elements composed of a tetrahedral framework of $\mathrm{SiO}_{4}$ and $\mathrm{AlO}_{4}$ [164].

Non-conservative and intensive agricultural practices can jeopardize water and soil quality; in fact, nowadays, it is necessary to implement mitigation management to safeguard water resources and to reduce nutrient loss in order to guarantee healthy environmental quality and a high-performance crop yield [165]. Zeolites were tested as a soil conditioner to increase irrigation efficiency (augmenting both water holding capacity and soil drainage) and diminish nutrient leaching [166,167]. They can facilitate greater efficiency of fertilizers or herbicides and limit leaching losses releasing nutrients or phytopharmaceutical molecules gradually for extended periods of time [168].

In vineyards, soils amended with zeolite showed higher nutrient availability and dehydrogenase activity. Moreover, a drop in humic substances was observed in the zeolitetreated soils, even though total organic carbon (TOC) content was unchanged, suggesting that the stimulation of soil microbial processes by adding zeolite sparked a microbial mineralization procedure of organic carbon stocks. In addition, pyrolysis-gas chromatography (Py-GC) showed a modification in soil organic matter (SOM) chemical composition in treated vineyards, with an increase in the labile aliphatic compound furfural and a dwindling in the more stable aromatic pyrolytic fragments (higher extent of decomposition of the SOM more stable pool) [169].

The consequences of the application of $30 \mathrm{t} / \mathrm{ha}$ ZeoWine (zeolite added to organic compost) were directly reflected in the quantitative and qualitative characteristics of the grapes [170]. Due to the capacity to retain and release molecules of water up to $60 \%$ of their 
weight, ZeoWine improved the efficiency of water use and minimized water stress, leading the activity of the plant to maximize net photosynthesis and accumulation of substances of secondary metabolism. In the same way, a preparation of zeolite and dolomite enhanced the performance of the vines (sugar content up to $225 \mathrm{~g} / \mathrm{dm}^{3}$ ) by improving the characteristics of the soil [171].

In European vineyards, 1-2 kg Cu/ha/year were applied, reaching $20 \mathrm{~kg} \mathrm{Cu} / \mathrm{ha} / \mathrm{year}$ in Australian vineyards [172]. Works showed that $\mathrm{Cu}$ content in vineyard soils can exceed about three hundred times the natural concentration in soils (5-30 mg/kg) (Table 2).

Table 2. $\mathrm{Cu}$ content in vineyard soils.

\begin{tabular}{ccc}
\hline Country & $\mathbf{M g} / \mathbf{k g ~ C u}$ & Bibliography \\
\hline Australia & $40-250$ & {$[173]$} \\
\hline Brazil & $62-3200$ & {$[174,175]$} \\
\hline France & $100-1500$ & {$[176]$} \\
\hline Greece & $100-210$ & {$[177]$} \\
\hline Italy & $50-300$ & {$[178]$} \\
\hline Spain & $35-600$ & {$[179]$} \\
\hline Taiwan & $9-100$ & {$[180]$} \\
\hline
\end{tabular}

$\mathrm{Cu}$ toxicity symptoms are generally a reduction in root growth, abnormal ramifications. In the shoots, there are usually chlorosis symptoms, with reducing chlorophyll concentration and changes in the chloroplasts structure and in the composition of thylakoids' membranes [181,182]. Natural zeolite material was applied in numerous Cu-polluted soil remediation engineering cases, due to its strong ion exchange/adsorption capacity [183]. However, even if, to date, investigations on the soil of contaminated vineyards do not exist, zeolites could also be applied to vineyard soils to study their benefits for copper reduction.

It is believed that the use of zeolites provides significant improvements to the viticultural ecosystem, which is better able to restore its stability when subjected to disturbances (water stress and excess heavy metals).

\subsection{Transport and Uptake Soil Water-Partial Root Drying}

Grapevine root development and system structure are determined by both genetic and environmental components [184]. Root system development is influenced by chemical and physical soil properties and by different rootstock genotypes, together with different rootstock-cultivar combinations [185]. Modifying of the root system distribution and density under water limitation revolves around rootstock genotypes, soil, and is apparently related to transcriptomic regulations, which could promote protein and sugar transport, osmotic adjustment, or suberin and wax production in roots [186]. The root hydraulic architectural structure, in addition to having quantitative implications on the yield of the plant, influences the explored soil volume through a greater number of root tips and a greater branching of the fibrous roots, with better access to water resources [187].

In a cool climate, excess vigor (root and canopy) is a problem in vineyards, due to the high soil nitrogen-fertility. The relationship between soil N-fertility and grapevine vigor was positively tested [188]. In soils with a high level of nitrogen, vigor reduction is possible in vines when the root system is split into two halves and one half is kept under a dry regime while the other half is kept under a wet regime (partial root drying-PRD). The PRD technique is focused on the direct sensing of the soil moisture status by the roots and it necessitates that the root zone is concurrently exposed to drying soil (the other root half) and wet soil (half of the root system), respectively. In this way, the watered-side roots maintain the water status of the vine, while the dehydrating roots transmit chemical signals to the shoots via xylem [189]. The roots under dry conditions release a stress-related hormone, abscisic acid (ABA), which signals the vine to reduce leaf growth and partially 
close the stomata $[190,191]$. This technique showed quality improvement for grapevines grown in regions of low rainfall that need irrigation to maintain production at economic levels. In Australian vineyards, for fourteen days, irrigation was applied to one side of a grapevine's root system, while the opposite side that was dry for ten to fifteen days, was then irrigated for the same time (this drying/wetting cycle was maintained for all the growing season) [192]. In cv. Tempranillo vines, under semi-arid conditions, it was demonstrated that PRD helps in controlling excessive vegetative growth and improves grape quality without reducing clusters' production [193].

Long-term, large-scale field experiments on Riesling, Shiraz, and Cabernet Sauvignon, using PRD irrigation methods, were conducted. These included standard drip emitters (two or four $\mathrm{L} / \mathrm{h}$ ), two per vine, placed about $450 \mathrm{~mm}$ from the vine trunk and subsurface drip lines, one on each side of the vine row (depth 200-250 mm) [194]. Due to the vegetative and reproductive balance, the beneficial effects for the berry composition and metabolism were documented, improving fruit color and anthocyanin concentrations in red varieties in addition to showing a rise in total phenols [195]. In Vitis vinifera L. cv. Castelão, in Southern Portugal, the PRD irrigation technique ( $50 \%$ of the crop evapotranspiration-ETc) was successfully proposed for viticulture as a possible way to save water without compromising yield [196]. Briefly, the true environmental cost of irrigation water justifies the cost of implementing PRD (water-saving); the additional outlay of installing PRD is economical where the cost of irrigation water is high and as water becomes an increasingly scarce and valuable resource.

In light of these results, it is believed that partial root drying is an improving technique from the point of view of sustainability (water-saving) but is more applicable to cultivation in pots than in the open field.

\subsection{Cover Cropping and Mulching}

Conservative and sustainable soil management techniques, such as mulching and cover cropping, compared to conventional tillage, have an essential contribution in safeguarding soil fertility, biodiversity, and supporting the vegetative-productive balance.

Cover cropping decreases runoff and heightens water infiltration that bolsters water filling of the soil profile in winter and makes more water available for both crops during their growth cycles [197]. Nevertheless, studies of competition for water resources between intercrop and grapevine generated conflicting results. Some studies showed greater water stress in intercropped vineyards, while others highlighted that grapevines grown with a cover crop did not always exhibit higher water stress than those grown with bare soil [198].

As regards the aspect of climate change, it was demonstrated that vineyards' cover cropping had the ability to reduce nitrous oxide $\left(\mathrm{N}_{2} \mathrm{O}\right)$ emissions relative to conventional techniques. $\mathrm{N}_{2} \mathrm{O}$ is a greenhouse gas produced from denitrification, nitrifier-denitrification, and nitrification processes; it is responsible for global warming and the shattering of the ozone layer. A $35 \%$ increase in $\mathrm{N}_{2} \mathrm{O}$ emissions was recorded after mineral and organic fertilizers application to the soils [199].

The reduction of sprays, the adoption of selective techniques, such as mating disruption as well as cover cropping are the first steps to increase the environmental sustainability of the integrated pest management (IPM) system [200]. Cover crops were shown to enhance the abundance of several natural enemies and even to increase the predation and parasitism of pests. The effect of the increased shelter provided by a cover crop was demonstrated by the abundance of a range of predators (spiders, beetles, and brown lacewings) in the canopy and on the ground [201].

A research trial was conducted to evaluate the effects of grass cover cropping on grapevine production and quality. Summarizing the results in terms of cover crop and grapevine competition, the species were grouped into three categories:

- Highly competitive (L. perenne and F. arundinacea).

- Minimally competitive (F. ovina, F. rubra subsp. rubra and P. pratensis).

- Growth-stimulating (leguminous crops). 
The higher amount of $\mathrm{N}$ supplied by leguminous cover crops stimulated the canopy, and grape growth, increasing the yield and pruning weight. Highly competitive graminaceous crops used soil resources (mineral nutrients and $\mathrm{H}_{2} \mathrm{O}$ ) intensely, thus reducing vine vegetative development (less shoot weight and reduced leaf area) and yield (40-50\% less than with leguminous crops) but producing a higher sugar content. Minimally competitive graminaceous species maintained balanced grapevines in terms of these qualities [202].

The use of cover crops reduced the leaf area, and consequently minimized transpiration losses, with decreasing mechanization canopy practices [203].

Another potential adaptation measure that needs to be considered and further studied is the application of mulches [204]. Mulches are inorganic or organic materials that may be placed on the soil surface. Mulching retains soil moisture, reduces soil compaction, reduces evaporation, regulates soil temperature, improves soil quality, and increases its organic matter content. Furthermore, mulching is an affordable agricultural technology for sustainable soil, promoting a reduction in soil erosion, and can be easily adopted by farmers [205].

By adopting the STICS process-based crop model to simulate future (2021-2080) grapevine yields in eight sub-regions of Alentejo (Portugal), a study [205] assessed the adaptation potential of mulching for maintaining existing grapevine yield levels. Under the climate change scenario RCP8.5, these simulations put in comparison, over the next 60 years, mulching and non-mulching experiments. The prediction was of a general reduction in production in the future; however, mulching mitigated these decreases by $10 \%$ to $25 \%$. Mulching was considered a cost-effective adaptation measure, which could be easily adopted by winemakers in the short term.

Mulching should be used as a technique to reduce soil evaporation (E) for improving crop water use efficiency (WUE). The effect of using pruning waste as an organic mulching was analyzed on vineyard evapotranspiration (ETc). The results showed a reduction in the vineyard ETc between $16 \%$ and $18 \%$ with the organic mulching, and up to $24-30 \%$ with the plastic mulching [206]. Combining organic mulch and no-tillage was useful in reducing direct soil water loss and limiting early transpiration losses. However, mulched and no-tilled soils showed a higher bulk density in the shallower soil layer, along with a lower saturated hydraulic conductivity [207].

Micro-sprinkler and mulching reduced $\mathrm{N}_{2} \mathrm{O}$ emissions by $29 \%$, suggesting bark mulch as a strategy for mitigating $\mathrm{N}_{2} \mathrm{O}$ emission [208]. However, the mechanism by which bark mulch reduces $\mathrm{N}_{2} \mathrm{O}$ emissions is not clear, and further investigation using isotopic and/or molecular techniques is warranted.

Other results on Cabernet Sauvignon cv. indicate that mulching can be a valuable tool for enhancing wine quality in soils with low water availability; briefly, the sugar content was more balanced $\left(27.9^{\circ}\right.$ Brix $)$ while maintaining an excellent anthocyanin $(1876.83 \mathrm{mg} / \mathrm{L})$ and total polyphenol (3976.97 mg/L) content [209].

Therefore, it is believed that the use of mulching in semi-arid conditions could be more beneficial, in order to preserve and exploit the residual moisture in the soil.

\section{Conclusions}

Viticulture is facing emerging challenges not only because of the effect of global warming on the yield and berries composition, but also of a social demand for environmentally friendly agricultural management. Adaptation to these challenges is important to guarantee the sustainability of viticulture.

Therefore, vineyards must benefit from and contribute to conservation and ecosystem services provision, especially as wine consumers increasingly appreciate environmentally friendly farming practices. Fortunately, nowadays, there is an increasing interest in conservative and sustainable soil management techniques. Correct and non-destructive soil management is used as a practice for promoting biodiversity, efficiency of the use of nutrients, and soil organic matter. In addition, considering climate change and rising temperatures, targeted soil management is a valuable aid for winemakers to preserve 
water content and guarantee quality in production. In fact, soil represents a non-renewable resource, and it is an open system in dynamic equilibrium with the other environmental components and in continuous evolution. These components must be enhanced to optimize the quality of the product and the resilience of the system. Resilience must be the aim of a viticultural ecosystem to guarantee the renewability of resources. To improve the quality of modern viticulture, the step is represented by sustainable management that leads to a safe and healthy economy without compromising the resources of future generations. These practices are, therefore, valuable tools for balance in the viticultural ecosystem and to enhance the quality of production.

Author Contributions: E.C. wrote and revised the original draft manuscript, which was improved by G.B.M. M.F. contributed to bibliographic research. All authors have read and agreed to the published version of the manuscript.

Funding: This research did not receive any specific grant from funding agencies in the public, commercial, or not-for-profit sectors.

Institutional Review Board Statement: Not applicable.

Informed Consent Statement: Not applicable.

Conflicts of Interest: All the other authors have no conflicts of interest with the trial carried out.

\section{References}

1. Fraga, H. Viticulture and Winemaking under Climate Change. Agronomy 2019, 9, 783. [CrossRef]

2. Kibblewhite, M.G.; Ritz, K.; Swift, M.J. Soil health in agricultural systems. Philos. Trans. R. Soc. B Biol. Sci. 2008, 363, 685-701. [CrossRef]

3. Polge de Combret-Champart, L.; Guilpart, N.; Mérot, A.; Capillon, A.; Gary, C. Determinants of the degradation of soil structure in vineyards with a view to conversion to organic farming. Soil Use Manag. 2013, 29, 557-566. [CrossRef]

4. Komárek, M.; Čadková, E.; Chrastný, V.; Bordas, F.; Bollinger, J.C. Contamination of vineyard soils with fungicides: A review of environmental and toxicological aspects. Env. Int. 2010, 36, 138-151.

5. Raclot, D.; Le Bissonnais, Y.; Louchart, X.; Andrieux, P.; Moussa, R.; Voltz, M. Soil tillage and scale effects on erosion from fields to catchment in a Mediterranean vineyard area. Agric. Ecosyst. Environ. 2009, 134, 201-210. [CrossRef]

6. Chopin, E.I.B.; Marin, B.; Mkoungafoko, R.; Rigaux, A.; Hopgood, M.J.; Delannoy, E.; Cances, B.; Laurain, M. Factors affecting distribution and mobility of trace elements $(\mathrm{Cu}, \mathrm{Pb}, \mathrm{Zn})$ in a perennial grapevine (Vitis vinifera $\mathrm{L}$.) in the Champagne region of France. Environ. Pollut. 2008, 156, 1092-1098. [CrossRef]

7. Paredes, D.; Rosenheim, J.A.; Chaplin-Kramer, R.; Winter, S.; Karp, D.S. Landscape simplification increases vineyard pest outbreaks and insecticide use. Ecol. Lett. 2021, 24, 73-83. [CrossRef]

8. Lohar, R.R.; Hase, C.P. Sustainable Agricultural Practices for the Improvement of Growth and Yield of some Important Crops popular in Walwa-tehsil, district Sangli (Maharashtra) A Review. J. Plant. Sci. Res. 2021, 37, 133-143.

9. Preston, W.; da Silva, Y.J.; do Nascimento, C.W.; da Cunha, K.P.; Silva, D.J.; Ferreira, H.A. Soil contamination by heavy metals in vineyard of a semiarid region: An approach using multivariate analysis. Geoderma Reg. 2016, 7, 357-365. [CrossRef]

10. Brunetto, G.; Ferreira, P.A.A.; Melo, G.W.; Ceretta, C.A.; Toselli, M. Heavy metals in vineyards and orchard soils. Rev. Bras. Frutic. 2017, 39, e-263. [CrossRef]

11. Komárek, M.; Száková, J.; Rohošková, M.; Javorská, H.; Chrastný, V.; Balík, J. Copper contamination of vineyard soils from small wine producers: A case study from the Czech Republic. Geoderma 2008, 147, 16-22. [CrossRef]

12. Pietrzak, U.; Uren, N.C. Remedial options for copper-contaminated vineyard soils. Soil Res. 2011, 49, 44-55. [CrossRef]

13. Mackie, K.A.; Müller, T.; Kandeler, E. Remediation of copper in vineyards-A mini review. Environ. Pollut. 2012, 167, 16-26. [CrossRef] [PubMed]

14. Sun, X.; Ma, T.; Han, L.; Huang, W.; Zhan, J. Effects of copper pollution on the phenolic compound content, color, and antioxidant activity of wine. Molecules 2017, 22, 726. [CrossRef] [PubMed]

15. Claus, H. How to deal with uninvited guests in wine: Copper and copper-containing oxidases. Fermentation 2020, 6, 38. [CrossRef]

16. Gutiérrez-Gamboa, G.; Zheng, W.; Martínez de Toda, F. Strategies in vineyard establishment to face global warming in viticulture: A mini review. J. Sci. Food Agric. 2021, 101, 1261-1269. [CrossRef]

17. Webb, L.B.; Whetton, P.H.; Barlow, E.W.R. Climate change and winegrape quality in Australia. Clim. Res. 2008, 36, 99-111. [CrossRef]

18. Hall, A.; Jones, G.V. Effect of potential atmospheric warming on temperature-based indices describing Australian winegrape growing conditions. Aust. J. Grape Wine Res. 2009, 15, 97-119. [CrossRef]

19. Sturman, A.; Quénol, H. Changes in atmospheric circulation and temperature trends in major vineyard regions of New Zealand. Int. J. Clim. 2013, 33, 2609-2621. [CrossRef] 
20. Seguin, B. Adaptation des systèmes de production agricole au changement climatique. C. R. Geosci. 2003, 335, 569-575. [CrossRef]

21. Briche, É.; Quénol, H.; Beltrando, G. Changement climatique dans le vignoble champenois. Lespace Geogr. 2011, 40, 164-175. [CrossRef]

22. Schulze, E.D. Carbon dioxide and water vapor exchange in response to drought in the atmosphere and in the soil. Annu. Rev. Plant. Physiol. 1986, 37, 247-274. [CrossRef]

23. McDowell, N.G. Mechanisms linking drought, hydraulics, carbon metabolism, and vegetation mortality. Plant. Physiol. 2011, 155, 1051-1059. [CrossRef]

24. Zhao, J.; Hartmann, H.; Trumbore, S.; Ziegler, W.; Zhang, Y. High temperature causes negative whole-plant carbon balance under mild drought. New Phytol. 2013, 200, 330-339. [CrossRef] [PubMed]

25. Smith, R.; Bettiga, L.; Cahn, M.; Baumgartner, K.; Jackson, L.E.; Bensen, T. Vineyard floor management affects soil, plant nutrition, and grape yield and quality. Calif. Agric. 2008, 62, 184-190. [CrossRef]

26. Steenwerth, K.; Belina, K.M. Cover crops enhance soil organic matter, carbon dynamics and microbiological function in a vineyard agroecosystem. Agric. Ecosyst. 2008, 40, 359-369. [CrossRef]

27. Bustamante, M.A.; Said-Pullicino, D.; Agulló, E.; Andreu, J.; Paredes, C.; Moral, R. Application of winery and distillery waste composts to a Jumilla (SE Spain) vineyard: Effects on the characteristics of a calcareous sandy-loam soil. Agric. Ecosyst. Environ. 2011, 140, 80-87. [CrossRef]

28. Calleja-Cervantes, M.E.; Fernández-González, A.J.; Irigoyen, I.; Fernández-López, M.; Aparicio-Tejo, P.M.; Menéndez, S. Thirteen years of continued application of composted organic wastes in a vineyard modify soil quality characteristics. Soil Biol. Biochem. 2015, 90, 241-254. [CrossRef]

29. Mackenzie, D.E.; Christy, A.G. The role of soil chemistry in wine grape quality and sustainable soil management in vineyards. Water Sci. Technol. 2005, 51, 27-37. [CrossRef] [PubMed]

30. Navel, A.; Martins, J.M. Effect of long term organic amendments and vegetation of vineyard soils on the microscale distribution and biogeochemistry of copper. Sci. Total Environ. 2014, 466, 681-689. [CrossRef] [PubMed]

31. Schreck, E.; Gontier, L.; Dumat, C.; Geret, F. Ecological and physiological effects of soil management practices on earthworm communities in French vineyards. Eur. J. Soil Biol. 2012, 52, 8-15. [CrossRef]

32. Peregrina, F.; Larrieta, C.; Ibáñez, S.; García-Escudero, E. Labile organic matter, aggregates, and stratification ratios in a semiarid vineyard with cover crops. Soil Sci. Soc. Am. J. 2010, 74, 2120-2130. [CrossRef]

33. Mazzoncini, M.; Sapkota, T.B.; Barberi, P.; Antichi, D.; Risaliti, R. Long-term effect of tillage, nitrogen fertilization and cover crops on soil organic carbon and total nitrogen content. Soil Tillage Res. 2011, 114, 165-174. [CrossRef]

34. Ruiz-Colmenero, M.; Bienes, R.; Eldridge, D.J.; Marques, M.J. Vegetation cover reduces erosion and enhances soil organic carbon in a vineyard in the central Spain. Catena 2013, 104, 153-160. [CrossRef]

35. Lal, R. Laws of sustainable soil management. In Sustainable Agriculture; Springer: Dordrecht, The Netherlands, 2009 ; pp. 9-12.

36. Jog, R.; Nareshkumar, G.; Rajkumar, S. Enhancing soil health and plant growth promotion by actinomycetes. In Plant Growth Promoting Actinobacteria; Springer: Singapore, 2016; pp. 33-45.

37. Thomsen, M.; Faber, J.H.; Sorensen, P.B. Soil ecosystem health and services-Evaluation of ecological indicators susceptible to chemical stressors. Ecol. Indic. 2012, 16, 67-75. [CrossRef]

38. Gyaneshwar, P.; Kumar, G.N.; Parekh, L.J.; Poole, P.S. Role of soil microorganisms in improving P nutrition of plants. Plant Soil 2002, 245, 83-93. [CrossRef]

39. Koch, A.; McBratney, A.; Adams, M.; Field, D.; Hill, R.; Crawford, J.; Minasny, B.; Lal, R.; Abbott, L.; O’Donnell, A.; et al. Soil security: Solving the global soil crisis. Glob. Policy 2013, 4, 434-441. [CrossRef]

40. Sharma, I.P.; Chandra, S.; Kumar, N.; Chandra, D. PGPR: Heart of soil and their role in soil fertility. In Agriculturally Important Microbes for Sustainable Agriculture; Springer: Singapore, 2017; pp. 51-67.

41. Bünemann, E.K.; Bongiorno, G.; Bai, Z.; Creamer, R.E.; De Deyn, G.; de Goede, R.; Fleskens, L.; Geissen, V.; Kuyper, T.W.; Mader, P.; et al. Soil quality-A critical review. Soil Biol. Biochem. 2018, 120, 105-125. [CrossRef]

42. Doran, J.W.; Parkin, T.B. Defining and assessing soil quality. Defin. Soil Qual. A Sustain. Environ. 1994, 35, 1-21.

43. Singer, M.J.; Sojka, R.E. Soil quality. Sci. Technol. 2002, 312-314.

44. Riches, D.; Porter, I.J.; Oliver, D.P.; Bramley, R.G.V.; Rawnsley, B.; Edwards, J.; White, R.E. Soil biological properties as indicators of soil quality in Australian viticulture. Aust. J. Grape Wine Res. 2013, 19, 311-323.

45. Coll, P.; Le Cadre, E.; Blanchart, E.; Hinsinger, P.; Villenave, C. Organic viticulture and soil quality: A long-term study in Southern France. Agric. Ecosyst. 2011, 50, 37-44. [CrossRef]

46. Haynes, R.J. Labile organic matter fractions and aggregate stability under short-term, grass-based leys. Soil Biol. Biochem. 1999, 31, 1821-1830. [CrossRef]

47. Morlat, R.; Chaussod, R. Long-term additions of organic amendments in a Loire Valley vineyard. I. Effects on properties of a calcareous sandy soil. Am. J. Enol Vitic. 2008, 59, 353-363.

48. Teixeira, R.F.M.; Domingos, T.; Costa, A.P.S.V.; Oliveira, R.; Farropas, L.; Calouro, F.; Barradas, A.M.; Carneiro, J.P.B.G. Soil organic matter dynamics in Portuguese natural and sown rainfed grasslands. Ecol. Model. 2011, 222, 993-1001. [CrossRef]

49. Wu, Y.; Xu, G.; Shao, H.B. Furfural and its biochar improve the general properties of a saline soil. Solid Earth 2014, 5, 665-671. [CrossRef] 
50. Delgado, A.; Gómez, J.A. The soil. Physical, chemical and biological properties. In Principles of Agronomy for Sustainable Agriculture; Springer: Cham, Switzerland, 2016; pp. 15-26.

51. Fränzle, O. Complex bioindication and environmental stress assessment. Ecol. Indic. 2006, 6, 114-136. [CrossRef]

52. Bagyaraj, D.J.; Nethravathi, C.J.; Nitin, K.S. Soil biodiversity and arthropods: Role in soil fertility. In Economic and Ecological Significance of Arthropods in Diversified Ecosystems; Springer: Singapore, 2016; pp. 17-51.

53. Zanella, A.; Ponge, J.F.; Briones, M.J. Humusica 1, article 8: Terrestrial humus systems and forms-Biological activity and soil aggregates, space-time dynamics. Agric. Ecosyst. 2018, 122, 103-137. [CrossRef]

54. Musbau, S.A.; Ayinde, B.H.; Omowunmi, O.O.; Motunrayo, E.L.; Belay, E.; Teshome, B.; Sarwar, M.T. Micro and Macro (Organisms) and Their Contributions to Soil Fertility. Front. Environ. Microbiol. 2021, 7, 44. [CrossRef]

55. Smith, P.; Cotrufo, M.F.; Rumpel, C.; Paustian, K.; Kuikman, P.J.; Elliott, J.A.; McDowell, R.; Griffiths, R.I.; Asakawa, S.; Bustamante, M.; et al. Biogeochemical cycles and biodiversity as key drivers of ecosystem services provided by soils. Soil 2015, 1, 665-685. [CrossRef]

56. Yuan, Y.; Jiang, Y.; Taguas, E.V.; Mbonimpa, E.G.; Hu, W. Sediment loss and its cause in Puerto Rico watersheds. Soil 2015, 1,595-602. [CrossRef]

57. Zornoza, R.; Acosta, J.A.; Bastida, F.; Domínguez, S.G.; Toledo, D.M.; Faz, A. Identification of sensitive indicators to assess the interrelationship between soil quality, management practices and human health. Soil 2015, 1, 173-185. [CrossRef]

58. Prosdocimi, M.; Jordán, A.; Tarolli, P.; Keesstra, S.; Novara, A.; Cerdà, A. The immediate effectiveness of barley straw mulch in reducing soil erodibility and surface runoff generation in Mediterranean vineyards. Sci. Total Environ. 2016, 547, 323-330. [CrossRef] [PubMed]

59. Heilig, J.; Kempenich, J.; Doolittle, J.; Brevik, E.C.; Ulmer, M. Evaluation of electromagnetic induction to characterize and map sodium-affected soils in the Northern Great Plains. Soil Surv. Horiz. 2011, 52, 77-88. [CrossRef]

60. Pitman, M.; Laüchli, A. Global impact of salinity and agricultural ecosystems. In Salinity: Environment-Plants-Molecules; Laüchli, A., Lullge, U., Eds.; Springer: Dordrecht, The Netherlands, 2004; pp. 3-20.

61. Wu, Y.P.; Zhang, Y.; Bi, Y.M.; Sun, Z.J. Biodiversity in saline and non-saline soils along the Bohai Sea coast, China. Pedosphere 2015, 25, 307-315. [CrossRef]

62. Lopez-Vicente, M.; Navas, A. Predicting soil erosion with RUSLE in Mediterranean agricultural systems at catchment scale. Soil Sci. 2000, 174, 272-282. [CrossRef]

63. Cerdà, A.; Giménez Morera, A.; García Orenes, F.; Morugán, A.; González Pelayo, Ó.; Pereira, P.; Lavee, H.; Romero-Díaz, A.; Hooke, J.; Montanarella, L. Soil erosion and degradation in mediterranean type ecosystems. Land Degrad. Dev. 2010, $21,71-74$. [CrossRef]

64. Marlet, S.; Bouksila, F.; Bahri, A. Water and salt balance at irrigation scheme scale: A comprehensive approach for salinity assessment in a Saharan oasis. Agric. Water Manag. 2009, 96, 1311-1322. [CrossRef]

65. Zalidis, G.; Stamatiadis, S.; Takavakoglou, V.; Eskridge, K.; Misopolinos, N. Impacts of agricultural practices on soil and water quality in the Mediterranean region and proposed assessment methodology. Agric. Ecosyst. Environ. 2002, 88, 137-146. [CrossRef]

66. Cerdà, A.; Keesstra, S.D.; Rodrigo-Comino, J.; Novara, A.; Pereira, P.; Brevik, E.; Gimenez-Morera, A.; Fernandez-Raga, M.; Pulido, M.; di Prima, S.; et al. Runoff initiation, soil detachment and connectivity are enhanced as a consequence of vineyards plantations. J. Environ. Manag. 2017, 202, 268-275. [CrossRef]

67. Rajwade, Y.A.; Swain, D.K.; Tiwari, K.N.; Mohanty, U.C.; Goswami, P. Evaluation of field level adaptation measures under the climate change scenarios in rice based cropping system in India. Environ. Process. 2015, 2, 669-687. [CrossRef]

68. García-Ruiz, J.M. The effects of land uses on soil erosion in Spain: A review. Catena 2010, 81, 1-11. [CrossRef]

69. Zhang, F.; Cui, Z.; Fan, M.; Zhang, W.; Chen, X.; Jiang, R. Integrated soil-crop system management: Reducing environmental risk while increasing crop productivity and improving nutrient use efficiency in China. J. Environ. 2011, 40, 1051-1057. [CrossRef]

70. Li, Z.; Lu, H.; Ren, L.; He, L. Experimental and modeling approaches for food waste composting: A review. Chemosphere 2013, 93, 1247-1257. [CrossRef]

71. Partanen, P.; Hultman, J.; Paulin, L.; Auvinen, P.; Romantschuk, M. Bacterial diversity at different stages of the composting process. BMC Microbiol. 2010, 10, 94. [CrossRef] [PubMed]

72. Azim, K.; Soudi, B.; Boukhari, S.; Perissol, C.; Roussos, S.; Alami, I.T. Composting parameters and compost quality: A literature review. Org. Agric. 2018, 8, 141-158. [CrossRef]

73. Komemoto, K.; Lim, Y.G.; Nagao, N.; Onoue, Y.; Niwa, C.; Toda, T. Effect of temperature on VFA's and biogas production in anaerobic solubilization of food waste. Waste Manag. 2009, 29, 2950-2955. [CrossRef] [PubMed]

74. Lu, S.G.; Imai, T.; Li, H.F.; Ukita, M.; Sekine, M.; Higuchi, T. Effect of enforced aeration on in-vessel food waste composting. Environ. Technol. 2001, 22, 1177-1182. [CrossRef] [PubMed]

75. Zhu, N. Effect of low initial C/N ratio on aerobic composting of swine manure with rice straw. Bioresour. Technol. 2007, 98, 9-13. [CrossRef]

76. Smårs, S.; Gustafsson, L.; Beck-Friis, B.; Jönsson, H. Improvement of the composting time for household waste during an initial low $\mathrm{pH}$ phase by mesophilic temperature control. Bioresour. Technol. 2002, 84, 237-241. [CrossRef]

77. Muscolo, A.; Papalia, T.; Settineri, G.; Mallamaci, C.; Jeske-Kaczanowska, A. Are raw materials or composting conditions and time that most influence the maturity and/or quality of composts? Comparison of obtained composts on soil properties. J. Clean. Prod. 2018, 195, 93-101. [CrossRef] 
78. Lou, X.F.; Nair, J. The impact of landfilling and composting on greenhouse gas emissions-A review. Bioresour. Technol. 2009, 100, 3792-3798. [CrossRef] [PubMed]

79. Kumar, M.; Ou, Y.L.; Lin, J.G. Co-composting of green waste and food waste at low C/N ratio. Waste Manag. 2010, 30, 602-609. [CrossRef] [PubMed]

80. Xi, B.D.; He, X.S.; Wei, Z.M.; Jiang, Y.H.; Li, M.X.; Li, D.; Li, Y.; Dang, Q.L. Effect of inoculation methods on the composting efficiency of municipal solid wastes. Chemosphere 2012, 88, 744-750. [CrossRef] [PubMed]

81. Colón, J.; Martínez-Blanco, J.; Gabarrell, X.; Artola, A.; Sánchez, A.; Rieradevall, J.; Font, X. Environmental assessment of home composting. Resour. Conserv. Recycl. 2010, 54, 893-904. [CrossRef]

82. Araújo, Y.R.V.; de Góis, M.L.; Junior, L.M.C.; Carvalho, M. Carbon footprint associated with four disposal scenarios for urban pruning waste. Environ. Sci. Pollut. Res. 2018, 25, 1863-1868. [CrossRef] [PubMed]

83. Guénon, R.; Gros, R. Soil microbial functions after forest fires affected by the compost quality. Land Degrad. Dev. 2016, 27, 1391-1402. [CrossRef]

84. Srivastava, P.K.; Gupta, M.; Singh, N.; Tewari, S.K. Amelioration of sodic soil for wheat cultivation using bioaugmented organic soil amendment. Land Degrad. Dev. 2016, 27, 1245-1254. [CrossRef]

85. Burg, P.; Vítěz, T.; Turan, J.; Burgová, J. Evaluation of grape pomace composting process. Acta Univ. Agric. Silv. Mendel. Brun 2014, 62, 875-881. [CrossRef]

86. Nerantzis, E.T.; Tataridis, P. Integrated enology-utilization of winery by-products into high added value products. J. Sci. Technol. 2006, 1, 79-89.

87. Diaz, M.J.; Madejon, E.; Lopez, F.; Lopez, R.; Cabrera, F. Optimization of the rate vinasse/grape marc for co-composting process. Process. Biochem. 2002, 37, 1143-1150. [CrossRef]

88. Eleonora, N.; Dobrei, A.; Dobrei, A.; Kiss, E.; Ciolac, V. Grape pomace as fertilizer. J. Hortic. Biotehnol. 2014, 18, 141-145.

89. Mugnai, S.; Masi, E.; Azzarello, E.; Mancuso, S. Influence of long-term application of green waste compost on soil characteristics and growth, yield and quality of grape (Vitis vinifera L.). Compos. Sci. Util. 2012, 20, 29-33. [CrossRef]

90. Martínez, M.M.; Ortega, R.; Janssens, M.; Fincheira, P. Use of organic amendments in table grape: Effect on plant root system and soil quality indicators. J. Soil Sci. Plant. Nutr. 2018, 18, 100-112. [CrossRef]

91. Gaiotti, F.; Marcuzzo, P.; Belfiore, N.; Lovat, L.; Fornasier, F.; Tomasi, D. Influence of compost addition on soil properties, root growth and vine performances of Vitis vinifera cv Cabernet sauvignon. Sci. Hortic. 2017, 225, 88-95. [CrossRef]

92. Pinamonti, F. Compost mulch effects on soil fertility, nutritional status and performance of grapevine. Nutr. Cycl. Agroecosyst. 1998, 51, 239-248. [CrossRef]

93. Adhikary, S. Vermicompost, the story of organic gold: A review. Agric. Sci. 2012, 3, 905-917. [CrossRef]

94. Lim, S.L.; Wu, T.Y.; Sim, E.Y.S.; Lim, P.N.; Clarke, C. Biotransformation of rice husk into organic fertilizer through vermicomposting. Ecol. Eng. 2012, 41, 60-64. [CrossRef]

95. Benitez, E.; Nogales, R.; Masciandaro, G.; Ceccanti, B. Isolation by isoelectric focusing of humic-urease complexes from earthworm (Eisenia fetida)-processed sewage sludges. Biol. Fertil. 2000, 31, 489-493. [CrossRef]

96. Jack, A.L.; Thies, J.E. Compost and vermicompost as amendments promoting soil health. In Biological Approaches to Sustainable Soil Systems; CRC Press: New York, NY, USA, 2006; pp. 453-466.

97. Sim, E.Y.S.; Wu, T.Y. The potential reuse of biodegradable municipal solid wastes (MSW) as feedstocks in vermicomposting. J. Sci. Food Agric. 2010, 90, 2153-2162. [CrossRef]

98. Khwairakpam, M.; Bhargava, R. Bioconversion of filter mud using vermicomposting employing two exotic and one local earthworm species. Bioresource 2009, 100, 5846-5852. [CrossRef]

99. Domínguez, J.; Gómez-Brandón, M. The influence of earthworms on nutrient dynamics during the process of vermicomposting Waste Manag. Res. 2013, 31, 859-868. [CrossRef] [PubMed]

100. Lim, S.L.; Wu, T.Y.; Lim, P.N.; Shak, K.P.Y. The use of vermicompost in organic farming: Overview, effects on soil and economics. J. Sci. Food Agric. 2015, 95, 1143-1156. [CrossRef]

101. Manivannan, S.; Balamurugan, M.; Parthasarathi, K.; Gunasekaran, G.; Ranganathan, L.S. Effect of vermicompost on soil fertility and crop productivity-beans (Phaseolus vulgaris). J. Environ. Biol. 2009, 30, 275-281.

102. Bouajila, K.; Sanaa, M. Effects of organic amendments on soil physico-chemical and biological properties. J. Mater. Environ. Sci. 2011, 2, 485-490.

103. Gopinath, K.A.; Saha, S.; Mina, B.L.; Pande, H.; Kundu, S.; Gupta, H.S. Influence of organic amendments on growth, yield and quality of wheat and on soil properties during transition to organic production. Nutr. Cycl. Agroecosyst. 2008, 82, 51-60. [CrossRef]

104. Paradelo, R.; Moldes, A.B.; Barral, M.T. Carbon and nitrogen mineralization in a vineyard soil amended with grape marc vermicompost. Waste Manag. Res. 2011, 29, 1177-1184. [CrossRef]

105. Bustamante, M.A.; Moral, R.; Paredes, C.; Pérez-Espinosa, A.; Moreno-Caselles, J.; Pérez-Murcia, M.D. Agrochemical characterisation of the solid by-products and residues from the winery and distillery industry. Waste Manag. 2008, 28, 372-380. [CrossRef]

106. Vinceslas-Akpa, M.; Loquet, M. Organic matter transformations in lignocellulosic waste products composted or vermicomposted (Eisenia fetida andrei): Chemical analysis and 13C CPMAS NMR spectroscopy. Soil Biol. Biochem. 1997, 29, 751-758. [CrossRef] 
107. Martínez, L.E.; Vallone, R.C.; Piccoli, P.N.; Ratto, S.E. Assessment of soil properties, plant yield and composition, after different type and applications mode of organic amendment in a vineyard of Mendoza, Argentina. Rev. Fac. Cienc. Agrar. 2018, 50, 17-32.

108. Zaninotti, S. How to improve the biological fertility of the soil in the vineyard. Inf. Agrar. 2013, 69, 36-39.

109. Koç, B.; Bellitürk, K.; Çelik, A.; Baran, M.F. Effects of Vermicompost and Liquid Biogas Fertilizer Application on Plant Nutrition of Grapevine (Vitis vinifera L.). Erwerbs Obstbau 2021, 63, 89-100. [CrossRef]

110. Ferreira, P.A.; Marchezan, C.; Ceretta, C.A.; Tarouco, C.P.; Lourenzi, C.R.; Silva, L.S.; Soriani, H.H.; Nicoloso, F.T.; Cesco, S.; Mimmo, T.; et al. Soil amendment as a strategy for the growth of young vines when replanting vineyards in soils with high copper content. Plant. Physiol. Biochem. 2018, 126, 152-162. [CrossRef]

111. Sirohi, R.; Tarafdar, A.; Singh, S.; Negi, T.; Gaur, V.K.; Gnansounou, E.; Bhartiraja, B. Green processing and biotechnological potential of grape pomace: Current trends and opportunities for sustainable biorefinery. Bioresour. Technol. 2020, $314,123771$. [CrossRef] [PubMed]

112. Igalavithana, A.D.; Mandal, S.; Niazi, N.K.; Vithanage, M.; Parikh, S.J.; Mukome, F.N.; Rizwan, M.; Oleszczuk, P.; Al-Wabel, M.; Bolan, N.; et al. Advances and future directions of biochar characterization methods and applications. Crit Rev. Environ. Sci. Technol. 2017, 47, 2275-2330. [CrossRef]

113. Schmidt, H.P.; Kammann, C.; Niggli, C.; Evangelou, M.W.; Mackie, K.A.; Abiven, S. Biochar and biochar-compost as soil amendments to a vineyard soil: Influences on plant growth, nutrient uptake, plant health and grape quality. Agric. Ecosyst. Environ. 2014, 191, 117-123. [CrossRef]

114. Atkinson, C.J.; Fitzgerald, J.D.; Hipps, N.A. Potential mechanisms for achieving agricultural benefits from biochar application to temperate soils: A review. Plant. Soil 2010, 337, 1-18. [CrossRef]

115. Major, J.; Rondon, M.; Molina, D.; Riha, S.J.; Lehmann, J. Maize yield and nutrition during 4 years after biochar application to a Colombian savanna oxisol. Plant. Soil 2010, 333, 117-128. [CrossRef]

116. Baronti, S.; Vaccari, F.P.; Miglietta, F.; Calzolari, C.; Lugato, E.; Orlandini, S.; Pini, R.; Zulian, C.; Genesio, L. Impact of biochar application on plant water relations in Vitis vinifera (L.). Eur. J. Agron. 2014, 53, 38-44. [CrossRef]

117. Kinney, T.J.; Masiello, C.A.; Dugan, B.; Hockaday, W.C.; Dean, M.R.; Zygourakis, K.; Barnes, R.T. Hydrologic properties of biochars produced at different temperatures. Biomass Bioenergy 2012, 41, 34-43. [CrossRef]

118. Genesio, L.; Miglietta, F.; Baronti, S.; Vaccari, F.P. Biochar increases vineyard productivity without affecting grape quality: Results from a four years field experiment in Tuscany. Agric. Ecosyst. Environ. 2015, 201, 20-25. [CrossRef]

119. Marshall, J.; Muhlack, R.; Morton, B.J.; Dunnigan, L.; Chittleborough, D.; Kwong, C.W. Pyrolysis temperature effects on biocharWater interactions and application for improved water holding capacity in vineyard soils. Soil Syst. 2019, 3, 27. [CrossRef]

120. Mackie, K.A.; Marhan, S.; Ditterich, F.; Schmidt, H.P.; Kandeler, E. The effects of biochar and compost amendments on copper immobilization and soil microorganisms in a temperate vineyard. Agric. Ecosyst. Environ. 2015, 201, 58-69. [CrossRef]

121. Giagnoni, L.; Maienza, A.; Baronti, S.; Vaccari, F.P.; Genesio, L.; Taiti, C.; Martellini, T.; Scodellini, R.; Cincinelli, A.; Costa, C.; et al. Long-term soil biological fertility, volatile organic compounds and chemical properties in a vineyard soil after biochar amendment. Geoderma 2019, 344, 127-136. [CrossRef]

122. Du Jardin, P. Plant biostimulants: Definition, concept, main categories and regulation. Sci. Hortic. 2015, 196, 3-14. [CrossRef]

123. EU. Regulation of the European Parliament and of the Council Laying Down Rules on the Making Available on the Market of EU Fertilising Products and Amending Regulations (EC) No 1069/2009 and (EC) No 1107/2009 and Repealing Regulation (EC) No 2003/2003. 2019. Available online: https:/ / eur-lex.europa.eu/legal-content/EN/TXT/?uri=OJ:L:2019:170:TOC (accessed on 9 November 2021).

124. Colla, G.; Rouphael, Y. Biostimulants in horticulture. Sci. Hortic. 2015, 196, 1-2. [CrossRef]

125. Pichyangkura, R.; Chadchawan, S. Biostimulant activity of chitosan in horticulture. Sci. Hortic. 2015, 196, 49-65. [CrossRef]

126. Canellas, L.P.; Olivares, F.L.; Aguiar, N.O.; Jones, D.L.; Nebbioso, A.; Mazzei, P.; Piccolo, A. Humic and fulvic acids as biostimulants in horticulture. Sci. Hortic. 2015, 196, 15-27. [CrossRef]

127. Colla, G.; Nardi, S.; Cardarelli, M.; Ertani, A.; Lucini, L.; Canaguier, R.; Rouphael, Y. Protein hydrolysates as biostimulants in horticulture. Sci. Hortic. 2015, 196, 28-38. [CrossRef]

128. Gómez-Merino, F.C.; Trejo-Téllez, L.I. Biostimulant activity of phosphite in horticulture. Sci. Hortic. 2015, 196, 82-90. [CrossRef]

129. Battacharyya, D.; Babgohari, M.Z.; Rathor, P.; Prithiviraj, B. Seaweed extracts as biostimulants in horticulture. Sci. Hortic. 2015, 196, 39-48. [CrossRef]

130. Savvas, D.; Ntatsi, G. Biostimulant activity of silicon in horticulture. Sci. Hortic. 2015, 196, 66-81. [CrossRef]

131. Rouphael, Y.; Franken, P.; Schneider, C.; Schwarz, D.; Giovannetti, M.; Agnolucci, M.; De Pascale, S.; Bonini, P.; Colla, G. Arbuscular mycorrhizal fungi act as biostimulants in horticultural crops. Sci. Hortic. 2015, 196, 91-108. [CrossRef]

132. Ruzzi, M.; Aroca, R. Plant growth-promoting rhizobacteria act as biostimulants in horticulture. Sci. Hortic. 2015, 196, 124-134. [CrossRef]

133. López-Bucio, J.; Pelagio-Flores, R.; Herrera-Estrella, A. Trichoderma as biostimulant: Exploiting the multilevel properties of a plant beneficial fungus. Sci. Hortic. 2015, 196, 109-123. [CrossRef]

134. Rouphael, Y.; Colla, G. Biostimulants in agriculture. Front. Plant. Sci. 2020, 11, 40. [CrossRef]

135. Okolie, C.L.; Mason, B.; Critchley, A.T. Seaweeds as a source of proteins for use in pharmaceuticals and high-value applications. In Novel Proteins for Food, Pharmaceuticals, and Agriculture: Sources, Applications, and Advances; John Wiley \& Sons: Hoboken, NJ, USA, 2018; p. 217. 
136. De Saeger, J.; Van Praet, S.; Vereecke, D.; Park, J.; Jacques, S.; Han, T.; Depuydt, S. Toward the molecular understanding of the action mechanism of Ascophyllum nodosum extracts on plants. J. Appl. Phycol. 2020, 32, 573-597. [CrossRef]

137. Shukla, P.S.; Mantin, E.G.; Adil, M.; Bajpai, S.; Critchley, A.T.; Prithiviraj, B. Ascophyllum nodosum-based biostimulants: Sustainable applications in agriculture for the stimulation of plant growth, stress tolerance, and disease management. Front. Plant Sci. 2019, 10, 655. [CrossRef]

138. Frioni, T.; VanderWeide, J.; Palliotti, A.; Tombesi, S.; Poni, S.; Sabbatini, P. Foliar vs. soil application of Ascophyllum nodosum extracts to improve grapevine water stress tolerance. Sci. Hortic. 2021, 277, 109807. [CrossRef]

139. Popescu, G.C.; Popescu, M. Effect of the brown alga Ascophyllum nodosum as biofertilizer on vegetative growth in grapevine (Vitis vinifera L.). Curr. Trends Nat. Sci. 2014, 3, 61-67.

140. Arioli, T.; Mattner, S.W.; Hepworth, G.; McClintock, D.; McClinock, R. Effect of seaweed extract application on wine grape yield in Australia. J. Appl. Phycol. 2021, 33, 1883-1891. [CrossRef]

141. Długosz, J.; Piotrowska-Długosz, A.; Kotwica, K.; Przybyszewska, E. Application of Multi-Component Conditioner with Clinoptilolite and Ascophyllum nodosum Extract for Improving Soil Properties and Zea mays L. Growth and Yield. Agronomy 2020, 10, 2005. [CrossRef]

142. Schreiner, R.P.; Bethlenfalvay, G.J. Mycorrhizal interactions in sustainable agriculture. Crit. Rev. Biotechnol. 1995, 15, $271-285$. [CrossRef]

143. Schreiner, R.P.; Mihara, K.L. The diversity of arbuscular mycorrhizal fungi amplified from grapevine roots (Vitis vinifera L.) in Oregon vineyards is seasonally stable and influenced by soil and vine age. Mycologia 2009, 101,599-611. [CrossRef] [PubMed]

144. Linderman, R.G.; Davis, E.A. Comparative response of selected grapevine rootstocks and cultivars to inoculation with different mycorrhizal fungi. Am. J. Enol. Vitic. 2001, 52, 8-11.

145. Nikolaou, N.; Angelopoulos, K.; Karagiannidis, N. Effects of drought stress on mycorrhizal and non-mycorrhizal Cabernet Sauvignon grapevine, grafted onto various rootstocks. Exp. Agric. 2003, 39, 241-252. [CrossRef]

146. Schreiner, R.P. Effects of native and nonnative arbuscular mycorrhizal fungi on growth and nutrient uptake of 'Pinot noir' (Vitis vinifera L.) in two soils with contrasting levels of phosphorus. Agric. Ecosyst. 2007, 36, 205-215. [CrossRef]

147. Harman, G.E.; Björkman, T.; Ondik, K.; Shoresh, M. Changing paradigms on the mode of action and uses of Trichoderma spp. for biocontrol. Outlooks Pest. Manag. 2008, 19, 24. [CrossRef]

148. Frankenberger, W., Jr.; Bingham, F.T. Influence of salinity on soil enzyme activities. Soil Sci. Soc. Am. J. 1982, 46, 1173-1177. [CrossRef]

149. Waldrop, M.P.; Balser, T.C.; Firestone, M.K. Linking microbial community composition to function in a tropical soil. Soil Biol. Biochem. 2000, 32, 1837-1846. [CrossRef]

150. Bonilla, N.; Gutiérrez-Barranquero, J.A.; Vicente, A.D.; Cazorla, F.M. Enhancing soil quality and plant health through suppressive organic amendments. Diversity 2012, 4, 475-491. [CrossRef]

151. Kleifeld, O.; Chet, I. Trichoderma harzianum-Interaction with plants and effect on growth response. Plant Soil 1992, 144, 267-272. [CrossRef]

152. Jain, A.; Singh, A.; Singh, S.; Singh, H.B. Biological management of Sclerotinia sclerotiorum in pea using plant growth promoting microbial consortium. J. Basic Microbiol. 2015, 55, 961-972. [CrossRef] [PubMed]

153. Poveda, J.; Hermosa, R.; Monte, E.; Nicolás, C. Trichoderma harzianum favours the access of arbuscular mycorrhizal fungi to non-host Brassicaceae roots and increases plant productivity. Sci. Rep. 2019, 9, 11650. [CrossRef]

154. Zhang, F.; Wang, Y.; Liu, C.; Chen, F.; Ge, H.; Tian, F.; Yang, T.; Ma, K.; Zhang, Y. Trichoderma harzianum mitigates salt stress in cucumber via multiple responses. Ecotoxicol. Environ. Saf. 2019, 170, 436-445. [CrossRef]

155. Altomare, C.; Tringovska, I. Beneficial soil microorganisms, an ecological alternative for soil fertility management. In Genetics, Biofuels and Local Farming Systems; Springer: Dordrecht, The Netherlands, 2011; pp. 161-214.

156. Sahu, P.K.; Singh, D.P.; Prabha, R.; Meena, K.K.; Abhilash, P.C. Connecting microbial capabilities with the soil and plant health: Options for agricultural sustainability. Ecol. Indic. 2019, 105, 601-612. [CrossRef]

157. McKee, L.S.; Inman, A.R. Secreted microbial enzymes for organic compound degradation. In Microbes and Enzymes in Soil Health and Bioremediation; Springer: Singapore, 2019; pp. 225-254.

158. Mbarki, S.; Cerdà, A.; Brestic, M.; Mahendra, R.; Abdelly, C.; Pascual, J.A. Vineyard compost supplemented with Trichoderma harzianum T78 improve saline soil quality. Land Degrad. Dev. 2017, 28, 1028-1037. [CrossRef]

159. D'Arcangelo, M.E.; Perria, R.; Zombardo, A.; Puccioni, S.; Valentini, P.; Storchi, P. Effect of treatment with products based on Trichoderma spp. on the development capacity of Sangiovese vines under replanting conditions. BIO Web Conf. EDP Sci. 2019, 13, 04017. [CrossRef]

160. Berlanas, C.; Andrés-Sodupe, M.; López-Manzanares, B.; Maldonado-González, M.M.; Gramaje, D. Effect of white mustard cover crop residue, soil chemical fumigation and Trichoderma spp. root treatment on black-foot disease control in grapevine. Pest. Manag. Sci. 2018, 74, 2864-2873. [CrossRef]

161. Rodríguez-González, Á.; Carro-Huerga, G.; Mayo-Prieto, S.; Lorenzana, A.; Gutiérrez, S.; Peláez, H.J.; Casquero, P.A. Investigations of Trichoderma spp. and Beauveria bassiana as biological control agent for Xylotrechus arvicola, a major insect pest in Spanish vineyards. J. Econ. Entomol. 2018, 111, 2585-2591. [CrossRef] [PubMed]

162. Berbegal, M.; Ramón-Albalat, A.; León, M.; Armengol, J. Evaluation of long-term protection from nursery to vineyard provided by Trichoderma atroviride SC1 against fungal grapevine trunk pathogens. Pest. Manag. Sci. 2020, 76, 967-977. [CrossRef] 
163. Eroglu, N.; Emekci, M.; Athanassiou, C.G. Applications of natural zeolites on agriculture and food production. J. Sci. Food Agric. 2017, 97, 3487-3499. [CrossRef]

164. Derbe, T.; Temesgen, S.; Bitew, M. A Short Review on Synthesis, Characterization, and Applications of Zeolites. Adv. Mater. Sci. Eng. 2021, 2021, 6637898. [CrossRef]

165. Cataldo, E.; Salvi, L.; Paoli, F.; Fucile, M.; Masciandaro, G.; Manzi, D.; Masini, C.M.; Mattii, G.B. Application of Zeolites in Agriculture and Other Potential Uses: A Review. Agronomy 2021, 11, 1547. [CrossRef]

166. Colombani, N.; Di Giuseppe, D.; Faccini, B.; Ferretti, G.; Mastrocicco, M.; Coltorti, M. Estimated water savings in an agricultural field amended with natural zeolites. Environ. Process. 2016, 3, 617-628. [CrossRef]

167. Nakhli, S.A.A.; Delkash, M.; Bakhshayesh, B.E.; Kazemian, H. Application of zeolites for sustainable agriculture: A review on water and nutrient retention. Water Air Soil Pollut. 2017, 228, 464. [CrossRef]

168. Campisi, T.; Abbondanzi, F.; Faccini, B.; Di Giuseppe, D.; Malferrari, D.; Coltorti, M.; Laurora, A.; Passaglia, E. Ammoniumcharged zeolitite effects on crop growth and nutrient leaching: Greenhouse experiments on maize (Zea mays). Catena 2016, 140, 66-76. [CrossRef]

169. Doni, S.; Gispert, M.; Peruzzi, E.; Macci, C.; Mattii, G.B.; Manzi, D.; Masini, C.M.; Grazia, M. Impact of natural zeolite on chemical and biochemical properties of vineyard soils. Soil Use Manag. 2020, 37, 832-842. [CrossRef]

170. Cataldo, E.; Salvi, L.; Mattii, G.B. ZEOWINE: The synergy between zeolite and compost. Effects on vine physiology and grape quality. Internet J. Vitic. Enol. 2021, 7, 1-3.

171. Pesic, V.; Korunoska, B.; Boskov, K. Effects of new organic preparations based on zeolite and dolomit over some characteristics of the grape in r. macedonia. J. Agric. Food Environ. Sci. JAFES 2017, 71, 125-131.

172. Chaignon, V.; Sanchez-Neira, I.; Herrmann, P.; Jaillard, B.; Hinsinger, P. Copper bioavailability and extractability as related to chemical properties of contaminated soils from a vine-growing area. Environ. Pollut. 2003, 123, 229-238. [CrossRef]

173. Wightwick, A.M.; Mollah, M.R.; Partington, D.L.; Allinson, G. Copper fungicide residues in Australian vineyard soils. J. Agric. Food Chem. 2008, 56, 2457-2464. [CrossRef] [PubMed]

174. Mirlean, N.; Roisenberg, A.; Chies, J.O. Metal contamination of vineyard soils in wet subtropics (southern Brazil). Environ. Pollut. 2007, 149, 10-17. [CrossRef]

175. Miotto, A.; Ceretta, C.A.; Brunetto, G.; Nicoloso, F.T.; Girotto, E.; Farias, J.G.; Tiecher, T.L.; De Conti, L.; Trentin, G. Copper uptake, accumulation and physiological changes in adult grapevines in response to excess copper in soil. Plant Soil 2014, 374, 593-610. [CrossRef]

176. Brun, L.A.; Maillet, J.; Hinsinger, P.; Pépin, M. Evaluation of copper availability to plants in copper-contaminated vineyard soils. Environ. Pollut. 2001, 111, 293-302. [CrossRef]

177. Vavoulidou, E.; Avramides, E.J.; Papadopoulos, P.; Dimirkou, A.; Charoulis, A.; Konstantinidou-Doltsinis, S. Copper content in agricultural soils related to cropping systems in different regions of Greece. Commun. Soil Sci. Plant Anal. 2005, 36, 759-773. [CrossRef]

178. Toselli, M.; Schiatti, P.; Ara, D.; Bertacchini, A.; Quartieri, M. The accumulation of copper in soils of the Italian region EmiliaRomagna. Plant. Soil Environ. 2009, 55, 74-79. [CrossRef]

179. Nóvoa-Muñoz, J.C.; Queijeiro, J.M.G.; Blanco-Ward, D.; Álvarez-Olleros, C.; Martínez-Cortizas, A.; García-Rodeja, E. Total copper content and its distribution in acid vineyards soils developed from granitic rocks. Sci. Total Environ. 2007, 378, 23-27. [CrossRef]

180. Lai, H.Y.; Juang, K.W.; Chen, B.C. Copper concentrations in grapevines and vineyard soils in central Taiwan. Soil Sci. Plant. Nutr. 2010, 56, 601-606. [CrossRef]

181. Tiecher, T.L.; Tiecher, T.; Ceretta, C.A.; Ferreira, P.A.; Nicoloso, F.T.; Soriani, H.H.; De Conti, L.; Kulmann, M.S.S.; Schneider, R.O.; Brunetto, G. Tolerance and translocation of heavy metals in young grapevine (Vitis vinifera) grown in sandy acidic soil with interaction of high doses of copper and zinc. Sci. Hortic. 2017, 222, 203-212. [CrossRef]

182. Ferreira, P.A.A.; Lourenzi, C.R.; Tiecher, T.; Tiecher, T.L.; Ricachenevsky, F.K.; Brunetto, G.; Giachini, A.J.; Soares, C.R.F.S. Physiological, Biochemical Changes, and Phytotoxicity Remediation in Agricultural Plant Species Cultivated in Soils Contaminated with Copper and Zinc. In Plants under Metal and Metalloid Stress; Springer: Singapore, 2018; pp. 29-76.

183. Yang, D.; Chu, Z.; Zheng, R.; Wei, W.; Feng, X.; Zhang, J.; Li, C.; Zhang, Z.; Chen, H. Remediation of Cu-polluted soil with analcime synthesized from engineering abandoned soils through green chemistry approaches. J. Hazard. Mater. 2021, 406, 124673. [CrossRef] [PubMed]

184. Marín, D.; Armengol, J.; Carbonell-Bejerano, P.; Escalona, J.M.; Gramaje, D.; Hernández-Montes, E.; Introgliolo, D.S.; MartínezZapater, J.M.; Medrano, H.; Mirás-Avalos, J.M.; et al. Challenges of viticulture adaptation to global change: Tackling the issue from the roots. Aust. J. Grape Wine Res. 2021, 27, 8-25. [CrossRef]

185. Kocsis, L.; Tarczal, E.; Molnár Kocsisné, G. Grape rootstock-scion interaction on root system development. In Proceedings of the I International Symposium on Grapevine Roots 1136, Rauscedo, Italy, 16-17 October 2014; pp. 27-32.

186. Yıldırım, K.; Yağc1, A.; Sucu, S.; Tunç, S. Responses of grapevine rootstocks to drought through altered root system architecture and root transcriptomic regulations. Plant. Physiol. Biochem. 2018, 127, 256-268. [CrossRef] [PubMed]

187. Gullo, G.; Dattola, A.; Vonella, V.; Zappia, R. Evaluation of water relation parameters in Vitis rootstocks with different drought tolerance and their effects on growth of a grafted cultivar. J. Plant. Physiol. 2018, 226, 172-178. [CrossRef] [PubMed]

188. Balachandra, L.; Edis, R.; White, R.E.; Chen, D. The relationship between grapevine vigour and N-mineralization of soil from selected cool climate vineyards in Victoria, Australia. J. Wine Res. 2009, 20, 183-198. [CrossRef] 
189. Dos Santos, T.P.; Lopes, C.M.; Rodrigues, M.L.; de Souza, C.R.; Maroco, J.P.; Pereira, J.S.; Silva, J.R.; Chaves, M.M. Partial rootzone drying: Effects on growth and fruit quality of field-grown grapevines (Vitis vinifera). Funct. Plant. Biol. $2003,30,663-671$. [CrossRef]

190. Davies, W.J.; Zhang, J. Root signals and the regulation of growth and development of plants in drying soil. Annu. Rev. Plant. Biol. 1991, 42, 55-76. [CrossRef]

191. Wheeler, S.J.; Pickering, G.J. Optimizing grape quality through soil management practices. Food Agric. Environ. 2003, 1, 190-197.

192. Düring, H.; Dry, P.R.; Botting, D.G.; Loveys, B. Effects of partial root-zone drying on grapevine vigour, yield, composition of fruit and use of water. In Proceedings of the Ninth Australian Wine Industry Technical Conference, Adelaide, SA, Australia, 16-19 July 1995; Winetitles: Broadview, SA, Australia, 1996; pp. 128-131.

193. Marsal, J.; Mata, M.; Del Campo, J.; Arbones, A.; Vallverdú, X.; Girona, J.; Olivo, N. Evaluation of partial root-zone drying for potential field use as a deficit irrigation technique in commercial vineyards according to two different pipeline layouts. Irrig. Sci. 2008, 26, 347-356. [CrossRef]

194. McCarthy, M.G.; Loveys, B.R.; Dry, P.R.; Stoll, M. Regulated deficit irrigation and partial rootzone drying as irrigation management techniques for grapevines. Deficit. Irrig. Pract. FAO Water Rep. 2002, 22, 79-87.

195. Spayd, S.E.; Tarara, J.M.; Mee, D.L.; Ferguson, J.C. Separation of sunlight and temperature effects on the composition of Vitis vinifera cv. Merlot berries. Am. J. Enol. Vitic. 2002, 53, 171-182.

196. Santos, T.P.; Lopes, C.M.; Rodrigues, M.L.; De Souza, C.R.; Ricardo-Da-Silva, J.M.; Maroco, J.P.; Pereira, J.S.; Chaves, M.M. Effects of partial root-zone drying irrigation on cluster microclimate and fruit composition of field-grown Castelão grapevines. Vitis 2015, 44, 117.

197. Celette, F.; Wery, J.; Chantelot, E.; Celette, J.; Gary, C. Belowground interactions in a vine (Vitis vinifera L.)-tall fescue (Festuca arundinacea Shreb.) intercropping system: Water relations and growth. Plant. Soil 2005, 276, 205-217. [CrossRef]

198. Celette, F.; Gaudin, R.; Gary, C. Spatial and temporal changes to the water regime of a Mediterranean vineyard due to the adoption of cover cropping. Eur. J. Agron. 2008, 29, 153-162. [CrossRef]

199. Marques, F.J.; Pedroso, V.; Trindade, H.; Pereira, J.L. Impact of vineyard cover cropping on carbon dioxide and nitrous oxide emissions in Portugal. Atmos. Pollut. Res. 2018, 9, 105-111. [CrossRef]

200. Burgio, G.; Marchesini, E.; Reggiani, N.; Montepaone, G.; Schiatti, P.; Sommaggio, D. Habitat management of organic vineyard in Northern Italy: The role of cover plants management on arthropod functional biodiversity. Bull. Entomol. Res. 2016, 106, 759-768. [CrossRef] [PubMed]

201. Thomson, L.J.; Hoffmann, A.A. Vegetation increases the abundance of natural enemies in vineyards. Biol. Control. 2009, 49, 259-269. [CrossRef]

202. Lavezzi, A.; Pascarella, G.; Sivilotti, P.; Tomasi, D.; Altissimo, A. Cover cropping systems in vineyard: Grass species and row management as affecting grapevine performance. In Proceedings of the XIV International GESCO Viticulture Congress, Geisenheim, Germany, 23-27 August 2005; pp. 635-641.

203. Pou, A.; Gulías, J.; Moreno, M.; Tomàs, M.; Medrano, H.; Cifre, J. Cover cropping in Vitis vinifera L. cv. Manto Negro vineyards under Mediterranean conditions: Effects on plant vigour, yield and grape quality. Oeno One 2011, 45, 223-234. [CrossRef]

204. Chan, K.Y.; Fahey, D.J.; Newell, M.; Barchia, I. Using composted mulch in vineyards—Effects on grape yield and quality. Int. J. Fruit Sci. 2010, 10, 441-453. [CrossRef]

205. Fraga, H.; Santos, J.A. Vineyard mulching as a climate change adaptation measure: Future simulations for Alentejo, Portugal. Agric. Syst. 2018, 164, 107-115. [CrossRef]

206. López-Urrea, R.; Sánchez, J.M.; Montoro, A.; Mañas, F.; Intrigliolo, D.S. Effect of using pruning waste as an organic mulching on a drip-irrigated vineyard evapotranspiration under a semi-arid climate. Agric. Meteorol. 2020, 291, 108064. [CrossRef]

207. Buesa, I.; Miras-Ávalos, J.M.; De Paz, J.M.; Visconti, F.; Sanz, F.; Yeves, A.; Guerra, D.; Intrigliolo, D.S. Soil management in semi-arid vineyards: Combined effects of organic mulching and no-tillage under different water regimes. Eur. J. Agron. 2021, 123, 126198. [CrossRef]

208. Fentabil, M.M.; Nichol, C.F.; Neilsen, G.H.; Hannam, K.D.; Neilsen, D.; Forge, T.A.; Jones, M.D. Effect of micro-irrigation type, $\mathrm{N}$-source and mulching on nitrous oxide emissions in a semi-arid climate: An assessment across two years in a Merlot grape vineyard. Agric. Water Manag. 2016, 171, 49-62. [CrossRef]

209. Cataldo, E.; Salvi, L.; Sbraci, S.; Storchi, P.; Mattii, G.B. Sustainable viticulture: Effects of soil management in Vitis vinifera. Agronomy 2020, 10, 1949. [CrossRef] 